\title{
The efficacy of back schools : empirical evidence and its impact on health care practice
}

Citation for published version (APA):

Keijsers, J. F. E. M. (1991). The efficacy of back schools : empirical evidence and its impact on health care practice. [Doctoral Thesis, Maastricht University]. Rijksuniversiteit Limburg. https://doi.org/10.26481/dis.19910621jk

Document status and date:

Published: 01/01/1991

DOI:

10.26481/dis.19910621jk

Document Version:

Publisher's PDF, also known as Version of record

\section{Please check the document version of this publication:}

- A submitted manuscript is the version of the article upon submission and before peer-review. There can be important differences between the submitted version and the official published version of record.

People interested in the research are advised to contact the author for the final version of the publication, or visit the DOI to the publisher's website.

- The final author version and the galley proof are versions of the publication after peer review.

- The final published version features the final layout of the paper including the volume, issue and page numbers.

Link to publication

\footnotetext{
General rights rights.

- You may freely distribute the URL identifying the publication in the public portal. please follow below link for the End User Agreement:

www.umlib.nl/taverne-license

Take down policy

If you believe that this document breaches copyright please contact us at:

repository@maastrichtuniversity.nl

providing details and we will investigate your claim.
}

Copyright and moral rights for the publications made accessible in the public portal are retained by the authors and/or other copyright owners and it is a condition of accessing publications that users recognise and abide by the legal requirements associated with these

- Users may download and print one copy of any publication from the public portal for the purpose of private study or research.

- You may not further distribute the material or use it for any profit-making activity or commercial gain

If the publication is distributed under the terms of Article $25 \mathrm{fa}$ of the Dutch Copyright Act, indicated by the "Taverne" license above, 


\title{
THE EFFICACY OF BACK SCHOOLS
}

\author{
Empirical evidence and \\ its impact on health care practice
}




\title{
THE EFFICACY OF BACK SCHOOLS
}

\author{
Empirical evidence and \\ its impact on health care practice
}

\author{
PROEFSCHRIFT
}

ter verkrijging van de graad van doctor aan de Rijksuniversiteit Limburg te Maastricht, op gezag van de Rector Magnificus, Prof. Mr. M.J. Cohen, volgens het besluit van het College van Dekanen, in het openbaar te verdedigen op vrijdag 21 juni 1991 om 16.00 uur

door

Johanna Francine Elisabeth Maria Keijsers 


\section{Promotores:}

Prof. Dr. G.J. Kok

Prof. Dr. P.G. Knipschild

\section{Co-promotor:}

Dr. L.M. Bouter

\section{Beoordelingscommissie:}

Prof. Dr. J.A. Knottnerus, (voorzitter)

Prof. Dr. H. Huijer Abu-Saad

Prof. Dr. G.J. Lankhorst, VU-zickenhuis Amsterdam

Dr. K.R. Lorig, Stanford University Medical Center, California, USA

Dr. F.J.N. Nijhuis

CIP DATA KOWNKLLUKE BIBLIOTHEEK DEN HAAG

Keijcers, Johanna Francine Elisabeth Maria

The efficacy of back schools : empirical ewidence and its impact on health care practice/Johanna Francine Elisabeth Maria Keijsers. - Maastricht: Datawyse. - III.

Thesis Maastricht. - With ref. - Wath summary in Dutch. ISBN 90-5291-053-7

NUGI 735

Subject headings: health education / back schools " efficacy.

Produktie en layout: Datawyse Maastricht, Ruud Leliveld Omslagontwerp: Guus van Rooy, AV-dienst RL

Druk: Krips Repro Meppel

Ven gedeelte van het in dit proefschrift beschreven onderzoek is gefinancierd door het Praeventiefonds.

De publicatie van dit proefschrift werd mede mogelijk gemaakt door financiële steun van de Catharina Pijls Stichting en de Rabobank te Geleen. 


\section{Contents}

CHAPTER I Introduction

CHAPTER 2 The efficacy of the back school:

an analysis of the literature

CHAPTER 3 A back school in the Netherlands:

evaluating the results

CHAPTER 4 Validity and comparability of studies on the effects of back schools

CHAPTER 5 The efficacy of the back school:

a randomized trial

CHAPTER 6 The impact of back school research on health care practice:

a randomized survey among general practitioners and physiotherapists

CHAPTER 7 Discussion

SUMMARY

SAMENVATTING

DANKWOORD

CURRICULUM VITAE 


\section{| Chapter 1}

\section{Introduction}

This dissertation is based on a research project into the efficacy of education and skills programs, the so-called back schools, designed for patients suffering from low back pain. In addition, it discusses the impact of the available empirical evidence concerning the efficacy of back schools on the opinion of physiotherapists and general practitioners.

Low back pain (LBP) is one of the most pervasive and costly problems facing health care today. In addition to personal suffering, low back pain accounts for a large amount of consumer health care utilization, employee absenteeism, reduced work productivity, disability and compensation payments (Brodie et al., 1990; Frymoyer et al., 1983). In most cases the complaints are self-limiting, with recovery within a few months in about $90 \%$ of the cases (Deyo, 1983; Spitzer et al., 1987; Waddell, 1987). Recurrences are frequent (40-60\%) (Haanen, 1984). The complaints are in most cases non-specific, which means that no clear underlying pathology can be established and the causes of the complaints remain unknown (Frymoyer, 1988; Nachemson, 1975). In the Netherlands, eight percent of all consultations with general practitioners involve such non-specific back complaints (Hoekstra, 1985). With regard to the duration of the complaint, LBP is usually sub-divided into acute (0-6 weeks), subacute (6-12 weeks) and chronic LBP (>12 weeks) (Frymoyer, 1988). The majority of patients with acute symptoms are commonly treated by means of (bed)rest, analgesic medications, exercises, traction and education. In 10 percent of patients, LBP persists for more than six weeks. In this subacute phase 5 to 10 percent of the patients require an operation because of herniation. With the exception of epidural steroids and braces, non-surgical treatment is similar to that given in the acute phase, although the analgesic medication is more specified. After three months, only 5 percent of the original number of patients still have symptoms (chronic phase). Most patients with chronic LBP benefit to some extent from anti-imflammatory medication and anti-depressants. Exercise programs and educational programs are popular additional treatments in this phase (Frymoyer, 1988).

Research in this subject area has called attention to the complex nature of low back pain and the need for a multidimensional approach (Fordyce, 1976; Melzack \& Wall, 1982). In addition to physical factors, it is generally assumed that 
psychosocial factors also play a substantial role in both the etiology and prognosis of low back pain. The gate-control theory (Melzack \& Wall, 1982) offers a neurophysiological basis for the role of these factors in the pain experience.

One popular and promising treatment for patients with non-specific low back pain is the 'back school', which is of Swedish origin (Zachrisson-Forssell, 1980).

Back schools offer an education and skills program in a group setting and primarily aim at self-management of pain. Information and training provide the patient with ways of dealing with pain, so that he/she will be able to control the pain problem better (Linton \& Kamwendo, 1987). A review of the literature concerning the contents of various back schools reveals that they show considerable differences. The content ranges from only discussing the physical factors related to low back pain to an additional discussion of the psychosocial aspects of low back pain. Consequently, the word back school does not refer to one specific education and skills program.

As will be pointed out in Chapter 2, most back schools do not approach pain in a multidimensional way. Furthermore, existing studies about the efficacy of back school treatment do not support the idea that back schools are very effective (Chapter 4). We therefore, in co-operation with the University Hospital of Maastricht, developed the so-called Maastricht back school. This back school consists of a wide range of elements which focus on a multidimensional approach of pain.

Motiwated by the lack of well-designed studies in the international literature, we decided to conduct a randomised trial on the efficacy of this Maastricht back school. Patients fulfilling certain selection criteria were randomly assigned to an experimental or a control group. The experimental group received the Maastricht back school treatment. The control group was promised and given the Maastricht back school treatment at the end of the study. It is generally accepted that a randomised trial is the most appropriate manner to obtain a valid assessment of treatment efficacy (Pocock, 1983).

We first tested the Maastricht back school in a randomised trial at the University Hospital of Maastricht. This pilot study indicated that the Maastricht back school program had little effect in patients with chronic non-specific low back pain (Chapter 3).

Subsequently, the idea was postulated that patients whose pain problem had not yet become chronic could benefit more from the Maastricht back school. It was hoped that the back school could perhaps disrupt the chronification process. Furthermore, no attempts had so far been made to measure the central goal of back school treatment (self-management of pain) directly. Therefore, a second randomised trial into the efficacy of the Maastricht back school was conducted in primary health care, aiming at patients with a relatively short pain duration. The most important measure of effect in this study was self-management of pain. The results of the study indicated that it is not very likely that the Maastricht back school is an effective way of managing non-specific low back pain (Chapter 5). 
Taken together, the results of both trials into the efficacy of the Maastrich back school do not support the idea that our back school is effective. The limited evidence available from other randomised trials indicates at most borderline effects for other back schools. Because of the warious selection criteria used and the different contents of back schools, it is not easy to compare and generalize these results. The results of the available studies are clearly not consistent. In other words, it is not clear which back school, if any, is effective for which subgroup of low back pain patients. Our overall conclusion is that back schools in the ir present set-up are not proven to be a very effective treatment for patients with non-specific low back pain.

We subsequently wondered whether people working in the field of primary health care would change their opinion as a consequence of the results of empirical research. We therefore conducted a randomised survey among general practitioners and physiotherapists (Chapter 6). The main question of the survey was to what extent these practitioners would change their opinion on the efficacy of back school treatment when confronted with a short overview of the research findings of all available randomised trials. The impact of the overview consisted of a change in opinion in the expected direction (a decreased belief in the efficacy of back school treatment), although somewhat smaller than expected.

Chapter 7 draws attention to the methodological limitations of the studies. Several possible explanations of the findings are presented. Furthermore, the chapter discusses to what extent our results can be generalized. Finally some recommendations for the treatment of low back pain are given. The English part of the dissertation then ends with a surnmary.

\section{References}

Brodie, D.J., Burnett, J.V., Walker, J.M., Lydes-Reid, D. (1990). Evaluation of low back pain by patient questionnaires and therapist assessment. JOSPT, 11, 519-529.

Deyo, R.A. (1983). Conservative therapy for low back pain. JAMA, 250, 1057-1062.

Fordyce, W.E. (1976). Behavioral methods for chronic pain and illness. Saint Lowis: The C.V. Mosby Company.

Frymoyer, J.W., Pope, M.H., Clements, J.H., Wilder, D.G., MacPherson, B., Ashikaga, T. (1983). Risk factors in low back pain: an epidemiological surwey. J Bone Joint Surg, 65-A, $213-218$.

Frymoyer, J.W. (1988). Back pain and sciatica. N Engl J Med, 318, 291-300.

Hoekstra, G.R. (1985). De rugpijnpatiënt in de huisartspraktijk [The low back pain patient in general practice]. In M.J. Kingma \& H.J. Dokter (Eds.), Rugpijn (pp. 40-66). Utrecht, The Netherlands: Bohn, Scheltema \& Holkema.

Haanen, H.C.M. (1984). Een epidemiologisch onderzoek naar lage rugpijn |Epidemiological research into low back pain]. Dissertation Uniwersity of Rotterdam, The Netherlands.

Linton, S.J., \& Kamwendo, K. (1987). Low back schools, A criticall review. Phys Ther, 67, $1375-1383$.

Melzack, R., \& Wall, P.D (1982). The challienge of pain. New York: Basic Books. 
Nachemson, A. (1975). Towards a better understanding of low back pain. Rheum Reh, 14 , $129-143$.

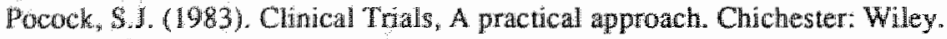

Spitzer, W.O.,LEBlanc, F.E., Dupuls, M. (1987). Scientific approach to the assessment and management of activity-related spinal disorders. Spine, 7 (Suppl. 1), $1-59$.

Waddel, G. (1987). A new clinical model for the treatment of low back pain. Spine, 12, $632-644$

Zachrison Forstell, M. (1980). The Swedish Back School. Physiotherapy, 66, 112-114. 


\title{
Chapter 2
}

\section{The efficacy of the back school}

\section{An analysis of the literature*}

Jolanda F.E.M. Keijsers, Mieke W.H.L. Steenbakkers, Frans M. Gerards \& Ree M. Meertens

* Published in Arthritis Care and Research 1990; 3: 210-215

\begin{abstract}
One of the possible treatments for patients suffering from low back pain is the so-called back school, which is of Swedish origin. Back schools offer an education and skills program in a group setting, directed towards pain management, and consisting of elements of education and/or training of skills. The contents and, briefly, the efficacy of all reported and evaluated back schools in a group setting are presented. Based on the different contents of back schools and the necessity of a multidimensional approach of low back pain, we have designed the Maastricht Back School to be a combination of all those elements about which we consider that a back school should give information and/or training.
\end{abstract}




\section{Introduction}

It is likely that up to $80 \%$ of all people will experience back pain to some extent during their active life (19). In most cases the complaints are self-limiting, with recovery within two or three months in $90 \%$ of cases (2). Recurrences are frequent $(40-60 \%)(6)$

The complaints are mostly non-specific, which means that no underlying pathology is established. In the Netherlands, eight percent of all consultations with general practitioners are related to these non-specific back complaints (8).

With regard to the duration of the complaint, low back pain is usually sub-divided into acute (0-6 weeks), subacute (6-12 weeks) and chronic low back pain ( $>12$ weeks) (5). The majority of patients with acute symptoms need only a non-specific short-term treatment regimen which may include bed rest, analgesic medications, exercises, traction and edlucation. In 10 percent of patients, low back pain persists for more than six weeks. In this subacute phase 5 to 10 percent of patients require an operation because of herniation. Non-surgical treatments are, with the exception of epidural steroids and braces, comparable to treatments in the acute phase, though the analgesic medication is more specified. After three months of low back pain, only 5 percent of patients have persisting symptoms (chronic phase). Most patients with chronic low back pain can be treated with anti-inflammatory medications and anti-depressants. Exercise programs and educational programs are popular treatments in this phase.

It is generally accepted that in addition to possible physical factors psychosocial factors are also involved in both etiology and prognosis of low back pain (17, 20,21 ). These factors are of equal importance in terms of treatment and they necessitate a multidimensional approach of low back pain (21).

One of the possible treatments for low back pain patients is the so-called back school, which is of Swedish origin (22). Back schools offer an education and skills program in a group setting (10-12 patients per group) and aim primarily at pain management: information is given about ways of dealing with pain, so that the patient is able to control the pain problem better (15). Ultimately this should lead to a decrease in work absentee ism and medical consumption.

In this article the contents and, briefly, the efficacy of all published back schools in a group setting are presented. Based on the different contents of back schools and the necessity of a multidimensional approach to low back pain, we have designed the Maastricht Back School to be a combination of all those elements about which we consider that a back school should give information and/or training. 


\section{Contents of back schools}

Table 1 shows an overview of the contents of all reported and evaluated back schools in a group setting. Individualized back schools such as the one reported on by Lindequist $e t a l$. (14) and clinical back schools such as that published by Aberg (1) are left out of consideration, for reasons of comparability.

The evaluation studies of Bergquist-Ullman \& Larsson (2), Lankhorst et al. (13), Hurri (9) and Klaber Moffett et al. (12) all aim at the efficacy of a back school based on the concept of the Swedish Back School. The Swedish Back School was developed by Zachrisson Forsell and consists of four 45-minute, mainly audio-visual, lessons under the supervision of a physiotherapist. During the first session different aspects of back disorders are discussed. The patients are given full details of the anatomy and function of the back. Various methods of treatment are discussed and the psoas position is taught. The entire course takes place in this position instead of in the seated position. During the second session the mechanicall strain in different positions and during different movements is discussed. The function of the muscles and their influence on the back is demonstrated. The patients are instructed in isometric abdominal muscle exercises and encouraged to continue these exercises every day. Back muscles exercises are discussed and the patients are told that these exercises expose the back to increase strain, with a risk of aggravation of the symptoms. The third session consists of praclical application of the previously acquired theoretical knowledge and is the most important part of the Swedish Back School. The patients are asked to describe their own work situation and the group endeavours to arrive at a suitable solution for each individual. The fourth and final session consists mainly of encouraging the patients to increase their level of physical activity during leisure hours in spite of their back disorder. A written summary of the principal contents of the Back School is provided. Additionally, patients attending the back school are allso offered one session of pool exercises under the supervision of a physiotherapist (22).

Bergquist-Ullman \& Larsson (2) have evaluated the effects of the Swedish Back School described above, combining this with an additional analysis of the working conditions of patients with acute low back pain. In their study, Lankhorst et al. (13) determine the efficacy of this Swedish Back School for patients suffering from chronic low back pain. In an evaluation study presented by Hurri (9), the Swedish Back School was extended to include a $2 \times 60$-minute review class after six months. The protocol presented by Klaber Moffett et al. (12) consists of three sessions. In the first session a simple introduction is given to the anatomy and biomechanics of the spine and common causes of low back pain are discussed, with maximum use of visual aids. Relaxation in the psoas resting position is demonstrated and practiced. Exercises aiming particularly at a strengthening of the abdominal muscles are taught. Session two consists of 
Table 1. Duraton and contents of back schools.

\begin{tabular}{|c|c|c|c|c|}
\hline & $\begin{array}{l}\text { Bergquist-UHman \& } \\
\text { Lairsemat (2) }\end{array}$ & Larikhorst ef al. (13y) & Humi (9) & Klaber Moffen ef al (12) \\
\hline Duration & $\begin{array}{l}4 \times 45 \text { min. sessions } \\
\text { during a } 2 \text {-wrek period }\end{array}$ & $\begin{array}{l}4 \times 45 \text { min, bessions } \\
\text { during a } 2 \text {-weck period }\end{array}$ & $\begin{array}{l}6 \times 60 \text { min. sessions } \\
\text { during a 3-week period }\end{array}$ & $\begin{array}{l}3 \times 60 \text { min. sessions } \\
\text { during a 1-week period }\end{array}$ \\
\hline Comintertits & 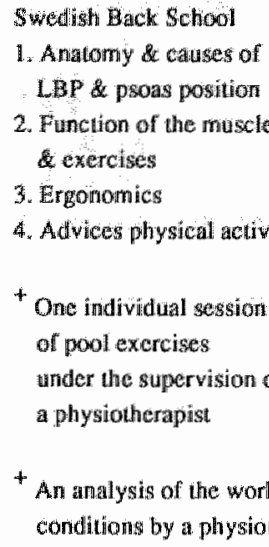 & $\begin{array}{l}\text { Swedish Back School } \\
\text { tis } \\
\text { nity } \\
\text { of } \\
\text { iking: } \\
\text { therapist }\end{array}$ & $\begin{array}{l}+ \text { A two } 60 \text {-minute } \\
\text { review class after } \\
\text { six momus }\end{array}$ & $\begin{array}{l}\text { 1. Anatomy \& causes of } \\
\text { LBP \& psoas position } \\
\text { \& excrcises } \\
\text { 2. Ergonomic counselling } \\
\text { 3. Occupational therapy }\end{array}$ \\
\hline
\end{tabular}

ergonomic counselling directed towards avoiding pain, with different positions being demonstrated and practiced. Various postures, including standing, sitting, lying, walking and lifting are discussed, with special regard to the inherent postural strain. Alternative positions are demonstrated and practiced. The third session aims at putting into practice methods already taught for carrying out functional activities with minimal strain on the spinal structures. In these interventions, which are all based on the Swedish Back School, there is no room for discussion of the psychosocial factors which influence back pain.

Mattmiller (16) has presented the California Back School, which consists of three sessions. During the first session of this back school resting positions, causes of low back pain and body mecharnics for individual occupations are discussed. In the second session an meeds-assessment is performed, which isolates problems concerning standing and sitting at work and about the house. Furthermore, coordination and isometric exercises are taught, and a training aimed at back protection at work is given. In the final session instruction is given on heavy lifting and cumbersome load-handling situations, making use of protective body mechanics. With regard to sports activities, patients are taught the basics of protective body mechanics. Mattmiller's back school (16) is again directed only to the physical aspects of low back pain. 
$3 \times 90$ min. sessions

during a 3 wewek period

Califoraia Back School

1. Resting positions causes of LAP \& body mechanics to individenal accupation

2. Dally life activities exercises \& back protection at work

3. Load handling \& sports activities

\# Review class after one rionth
$4 \times 90$ min. sessions

turing a 4 -week period

$1 \times$ thiour session

$7 \times 25$ how sessions

during a 7 -week period

\section{Canadian Back Bducation \\ 1. Avamorny} Units

1. Anatomy \& causes of WBP

2. Exercises

3. Emolion in pain s psychivatric aspects of LBP

4. Relaxation exercises

* 90-minute neview wlass after six months Pathophysiology Ergonomics Exercise Natural history Psychologic issues
Maastrich Back School

1. Pian history

2. Pigin

3. Amatomy causes of LBP

4. Posture

5. Psycholagical factors

6. Psychological fachors

7. Eualluation

1-7 Relaxation training 6. plizsical exorcises

* Review class after six months

The Canadian Back Education Units (7) offer four 90-minute sessions at weekly intervals. The first session, usually given by an orthopaedic surgeon, covers the anatomy, physiology and pathophysiology of back pain. The second session, presented by a physiotherapist, discusses the basis of physiotherapy and the effectiveness of back care. The role of proper exercise is explained and a simple ten-minute daily routine is advocated. The distinction between ways of effecting temporary relief and long term control with education and exercise is stressed. The third session, conducted by a psychiatrist, describes the place of emotions in chronic pain and the psychiatric aspects of back trouble. The patients are assured that their pain is never "all in the mind" and is therefore at least partially amenable to physical control. The fourth and final session is a practical demonstration. Relaxation exercises are demonstrated by a psychologist and patients practice the basic elements of flexion exercise and pelvic tilting with a physiotherapist. There is a 90 -minute review class after six months.

The back school described in an article by Berwick et al. (4) consists of a single 4-hour session of instruction about low back pain, taught by a specially trained orthopaedic nurse practitioner and a physical therapist. The material, which is not described in further detail in the article, deals with anatomy, pathophysiology, ergonomics, exercise, natural history and psychologic issues in back pain. Low back school subjects leave the session with an audiotape cassette 
of additional instruction and reinforcement of the low back school contents. In this back school, psychosocial factors are discussed in addition to physical factors, albeit very briefly.

In the Maastricht Back School developed by Keijsers et al. all possible factors influencing low back pain are discussed rather extensively (10). During the first session, a good deal of attention is directed towards acquainting the patients with one another and with the course instructor. The structure of the course is discussed and patients get the opportunity to tell their individual pain histories. After that, relaxation exercises are introduced. The relaxation training that the patients receive is a kind of progressive relaxation (3). The patients learn to tighten certain groups of muscles and then to relax them, moting in the process the difference in sensation. During each session, patients practice together. Eventually, the patient becomes capable of ewoking a relaxed feeling within a very short time in different situations. The exercises are to be practiced at home twice a day while listening to a pre-recorded cassette tape. The guest lecturer for the second session is a physician who giwes a layman's explanation of the gate-control theory of pain (18). The fact is stressed that pain is not influenced solely by physical factors, but also by psychological factors. The gate-control theory provides the structural framework for the rest of the course. In the third session, a physician talks about the structure of the back and about possible causes of back pain. It is hoped that by increasing the patients' knowledge, possible misunderstandings can be clarified. It is stressed that (chronic) back pain is often muscle pain, and, using a slide presentation, a physiotherapist demonstrates eight exercises that strenghten the muscles of the back and keep the body supple. The patients practice these exercises during the session and are asked to do this at home every day. Correct posture is demonstrated by a physiotherapist in the fourth session. In addition, general advice is given about foot-wear and sports training. A videotape is presented in which it is demonstrated how the patient should treat their backs when performing all kinds of daily activities such as self-care, work, household and leisure activities. Correct posture, as well as a number of daily activities are practiced with the patients. In this context, the patients repeat the exercises taught in session three under the guidance of the physiotherapist. In the sessions that follow, patients repeat these same exercises with the course instructor. In session five, a psychologist discusses the role of psychological factors in mental and physical tension in general and in back pain in particular. The patients are encouraged to consider the kinds of situations in which they are most troubled by back pain. They are also asked what they think about these situations and how they cope with them. In the sixth session, a psychologist discusses the influence of the environment on pain behavior and pain. It is pointed out that pain behavior and pain are often reinforced by positive consequences, such as the attention one gets, the rest one is allowed, and the medication one is given when one is in pain. At the beginning of the last session, a number of course evaluation questionnaires are filled out by the patients. The relaxation exercises are then completed. During 
Table 2. Elements about which information and/or tratning is given in back schools.

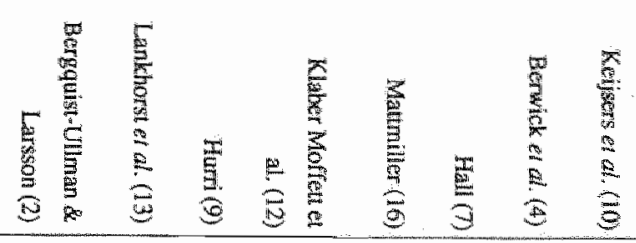

Physical Factors

$\begin{array}{lllllllll}\text { Anatomy } & \mathrm{x} & \mathrm{x} & \mathrm{x} & \mathrm{x} & \mathrm{x} & \mathrm{x} & \mathrm{x} & \mathrm{x} \\ \text { Causes LBP } & \mathrm{x} & \mathrm{x} & \mathrm{x} & \mathrm{x} & \mathrm{x} & \mathrm{x} & \mathrm{x} & \mathrm{x} \\ \text { Ergonomics } & \mathrm{x} & \mathrm{x} & \mathrm{x} & \mathrm{x} & \mathrm{x} & & \mathrm{x} & \mathrm{x} \\ \text { Psoms position } & \mathrm{x} & \mathrm{x} & \mathrm{x} & \mathrm{x} & \mathrm{x} & & & \mathrm{x} \\ \text { Exercises } & \mathrm{x} & \mathrm{x} & \mathrm{x} & \mathrm{x} & \mathrm{x} & \mathrm{x} & \mathrm{x} & \mathrm{x} \\ \text { Activity level } & \mathrm{x} & \mathrm{x} & \mathrm{x} & \mathrm{x} & \mathrm{x} & & & \mathrm{x}\end{array}$

Psychosocial Factors

Environment

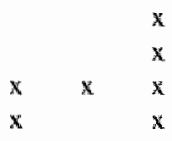

Cognitions

Emotions

Coping strategies

(e. g. relaxation)

the refresher session six months later, the individual sessions are repeated briefly and some important implications for managing one's back and the pain in everyday situations are stressed once more. In addition, a follow-up assessment is made at the end of the session.

The Maastricht Back School is designed to be a combination of all those elements about which we consider that a back school should give information and/or training. Table 2 shows that, compared to other back schools, the Maastricht Back School indeed approaches pain in a multidimensional way.

\section{Conclusion}

All the above-mentioned back schools have been evaluated in one way or another. The results from these studies indicate at most borderline effects of the back school. In some studies no positive effects of the back school were found $(4,13)$, Two studies did not even involve a control group $(7,16)$, so that it is almost impossible to draw any conclusions on the basis of these studies. In the remaining studies it was concluded that back school treatment was superior to a control group $(2,9,12)$. However, due to the number of effect parameters used, the number of significance tests performed led to an increased chance of finding at least one statistically significant effect. 
In another article in this joumal we present the results of a randomized trial on the efficacy of the Maastricht Back School in primary health care (11).

\section{References}

1 Aberg, $J$.: Ewaluation of an adyanced back pain rehabilitation program. Spine 3: 317$318,1984$.

2. Bergquist-ujlman, M. L Larsson, U.: Acute low back pain in industry. Acta Orthop Scand, Suppl $170,1977$.

3 Bernitein, D.A. B Borcovec, Th.D.: Progressive relaxation training. A manual for the helping professions. Research Press, Illinois, 1973.

4 Berwick, D.M., Budman, S. \& Feldstein, M.: No clinical effect of back schools in an HMO, A randomized prospective trial. Spine 3: 338-344, 1989.

5 Frymoyer, J.W.: Back pain and sciatica. N Engl J Med 318: 291-300, 1988.

6 Hanen, H.C.M.: Een epidemiologisch onderzoek naar lage rugpijn. Dissertation Erasmus University Rotherdam, The Neiherlands, 1984 .

7 Ha1l, H.: The Canadian Back Education Units. Physiotherapy 4: 115-117, 1980.

8 Hoekstra, G.R. : De rugpijnpatiênt in de huisartspraktijk. In Rugpijn (ed. M.J. Kingma \& H.J. Dokter), pp, 40 66. Bohn, Scheltema \& Holkema, Utrecht, 1987.

9 Hurri, H.: The Swedisth Back School in chronic low back pain, part 1 Benefits. Scand J Rehab Med 21: 33-40, 1989.

10 Keijsers, J.F.EM., Groenman, N.H., Gerards, F.M., van Oudheusden, E. \& Steenbakkers, W.H.L: A Back School in the Netherlands; Evaluating the results. Patient Education and Counseling $14: 31-44,1989$.

11 Keijsers, J.F.E.M., Steenbakkers, W.H.L., Meertens, R.M., Bouter, L.M. \& Kok G.J.: The efficacy of the back school. A randomized trial. Arthritis Care and Research 3: 204-209, 1990.

12 Klaber Moffett, J.A., Chase, S.M., Portek, I. \& Ennis, J.R.: A controlled, prospectiwe study to evaluate the effectiveness of a back school in the relief of chronic low back pain. Spine 2: 120-122, 1986.

13 Lankhorst, G.J., Van de Stadt, R.J., Vogelaar, T.W., Van der Korst, J.K. \& Prevo, A.J.H.: The effect of the Swedish Back School in chronic idiopathic low back pain. Scand J Rehab Med 15: 141-145, 1983.

14 Lindequist, S.L., Lundberg, B., Wikmark, R., Bergstad, B., Loof, G. \& Ottermark, A.C.: Information and regime at low back pain. Scand J Rehab Med 16:113-116,1984.

15 Linton, S.ll, \& Kamwendo, K.: Low back schools, A critical review. Phys Ther 9 : 1375-1383, 1987.

16 Matmiller, A.W.: The California Back School. Physiotherapy 4: 118-122, 1980.

17 Meitman, F. W.: The management of the chromic pain patient: clinical considerations. $J$ Orthop Sports Phys Ther 5: 305-317, 1984

I8 Melzack, R. \& Dennis, S.G.: Neurophysiology of Pain. In The Psychology of Pain (ed. R.A. Stembach). Ruven Press, New York, 1978.

19 Nachemson. A.L.: The lumbar spine: an orthopaedic challenge. Spine 1: $59-71,1976$.

20 Nachemson, A. A critical look at the treattment for low back pain. Scand $\$ Re hab Med $11: 143-147,1979$.

21 Turk, D.C. \& Flor, H.: Etiological theories and treatment for chronic back pain. II. Psychological models and interventions. Pain 19:209-233, 1984.

22 Zuchrisson Forssell, M.: The Swedish Back School. Physionerapy 4:112-114, 1981 


\title{
Chapter 3
}

\section{A back school in the Netherlands}

\section{Evaluating the results*}

Jolanda F.E.M. Keijsers, Nico H. Groenman, Frans M. Gerards, Ella van Oudheusden \& Mieke Steenbakkers

* Published in Patient Education and Counseling 1989; 14: $31-44$

\begin{abstract}
At the University Hospital of Maastricht the use of an education program for patients with chronic low back pain (Back School) has been investigated. The effect evaluation is based on a pretest-posttest-control group design, including a follow-up after eight weeks. The Maastricht Back School is based on the theory that pain is also maintained by emotional, cognitive and environmental factors. About these factors and about physical factors, information and training are given. The purpose of the course is to teach patients to manage their own pain problem. With the exception of somatic fixation and the seeking of social support, the results do not suggest the Back School program to be effective for patients with chronic low back pain.
\end{abstract}




\section{Introduction}

Chronic low back pain (LBP), that is pain that lasts longer than six months, appears to be a condition which is difficult to treat. A study by Haanen reveals that 50 to $60 \%$ of the Dutch population have, at one time or another, suffered from LBP. In 40 to $60 \%$ of the cases, it is a recurring condition. Moreover, Haanen concluded that in 5 to $6 \%$ of the population, sick-leaves of longer than six months were attributable to bouts of LBP (1). Characteristic of most back pain patients is a long somatic-medical history. For $90 \%$ of these patients, the cause of the pain is unknown $(2,3)$; yet, they are often subjected to long physical examinations and/or treatments with little, if any, success. This reinforces the patient's tendency to attribute the pain to somatic and/or medical causes. Frequently the result is that the pain increases and that the patient becomes somatically fixated.

Chronic LBP is increasingly being regarded as a problem that develops and is maintained by the interaction of physical, psychological and social factors. These factors are of equal importance in terms of treatment (4) and they necessitate a multidimensional approach. In the United States in particular, a number of pain management programs have been developed where LBP-patients actually "leam to live" better with their pain problem. Many of these programs have produced fair to good results (5). Cognitive and behavioral elements constitute an aspect of these pain management programs. The cognitive element is directed at thinking about pain, the behavioral element at what the patient and his environment do with the pain. In the Netherlands, too, a number of clinical and outpatient treatment programs have been developed; most of these, however, are still in the experimental stage $(6,7)$.

One such pain management program is conducted by the so-called "Back Schools". These schools mainly offer education courses and are not meant to be a form of psychotherapeutic intervention. The Back Schools have been developed more or less along the lines of the Swedish Back School (8). Courses given provide information about pain, the pain experience, and physical factors that may play a role in back pain. Information is also given about ways of dealing with pain, so that one is better able to control the pain problem. Back Schools do not approach the pain as a nociceptive problem but rather attempt to decrease the burden of the pain.

In the University Hospital in Maastricht, the Netherlands, a Back School has been developed and its results evaluated. After a review of factors that influence the pain, the present article gives an account of the content of the course and of the results of a pilot study.

\section{Pain}

Such factors as the importance that an individual attaches to a particular situation, priot experience, and one's present psychological state contribute significantly to 
the pain experience. Melzack and Wall (9) tried to incorporate this obserwation into their multidimensional model of pain: the gate-control theory. This theory describes the pain experience as the result of a complex interaction of sensorydiscriminative, affective-motivational and cognitive-evaluative systems. In addition, the physiological mechanisms of pain have multiple afferent and efferent effects; these ascending and descending neuronal systems modulate the nociceptive input. The theory offers a neurophysiological basis for the role of psychological factors in the pain experience (4). In the behavioral approach to chronic pain in particular, it is assumed that these psychological factors are partly responsible for the maintenance of pain. Such factors are expressed in terms of learning theory. In relation to this, five concepts deserve further attention: environment, cognitions, emotions, coping strategy and activities.

All these factors involved with pain are discussed rather extensively in the lessons taught at the Back School. These factors, in an operationalized form, also constituted the variables which were used to asses the success of the course. Pain intensity and the influence that the pain has on daily life were assessed as well.

\section{Environment}

A distinction must be made between pain and pain belnavior. Pain is an unpleasant sensory and emotional experience which is associated with real or potential tissue damage, or which is described in terms of such damage (10). A pain experience is something which one can only recognize indirectly by observing the facial expression, posture, speech, etc. of the person who is in pain. These are the pain behaviors and they, like any other form of behavior, are determined by the consequences they produce. If pain behavior is "rewarded", it eventually becomes controlled by the "rewarding" consequences. Such control becomes evident when the frequency of the pain behavior increases. Rewards for pain behavior include receiving attention, support, and care when one has pain; receiving medication each time one has a pain, rather than at fixed time intervals; and resting when one has a pain, rather than after exerting a certain amount of energy or after participating in a certain number of activities. The avoidance of unpleasant events can also be a reward for pain behavior, since pain often means no more threatening social contacts, no chores, and fewer family responsibilities (11).

\section{Cognitions}

Through such cognitive processes as labeling, anticipating and focusing attention, fear of serious diseases and physical complaints (pain) maintain one another. One speaks of labeling when the patient and/or the doctor attribute physical complaints to a physical cause. If this cause is serious enough, the label can become a source of anxious tension. Anxious tension can, in turn, evoke physical complaints. The minute a patient no longer has complaints, labeling can give way to anticipating. Anticipating pain is a form of anxious expectation. It evokes tension, 
which can, in turn, induce complaints. The processes of labeling and anticipating focus the patient"s attention strongly on certain areas of the body. Attention can then lower the perception threshold so that all kinds of sensations which, under nomal circumstances, are not felt suddenly become quite noticeable (12).

\section{Emotions}

Acute pain is related to the autonomic "fight-or-flight" reaction. One sees the same response pattern in anxiety attacks. In fact, most patients with acute pain also tend to experience anxiety. Chronic pain offers a different picture. Habituation of the autonomic responses takes place and the latter then fade away. A pattern of vegetative signals takes their place. This pattern is also seen in depressive reactions. The chronic pain and depression can coincide to such an extent that treatment of the depression often results in a dlecrease in pain. Similarly. treatment of the pain can reduce the depression (13).

\section{Coping strategy}

Another factor which influences the development of health complaints in general, and chronic pain complaints in particular, is the available and applied coping behavior. Coping behavior refers to the manner in which someone reacts behaviorally, cognitively, and emotionally to circumstances that require adjustment or adaptation (14). Though somewhat oversimplified, one could say that the experiencing and expressing of chronic pain complaints is, itsell $f$, a sort of coping behavior. The patient reacts by means of pain to circumstances that require adjustment.

\section{Activities}

Closely related to the four above-mentioned factors, and of considerable importance in the maintenance of chronic LBP, is the activity level of the patient. The most important physical deficiency is, in many cases, the deconditioning syndrome that is caused by prolonged inactivity of the back muscles and joints (15).

\section{Program}

The Maastricht Back School offers an education and skills program in a group setting for patients with chronic LBP. The program consists of seven lessons, each 2.5 hours لlong, plus a refresher lesson after eight weeks. The course instructors are present at every lesson. In addition, various guest lecturers are invited to present information related to LBP. During the first lesson, a good deal of attention is directed towards acquainting the patients with one another and with the course instructors. The guest lecturers for this lesson are a clinical psychologist and a clinical pedagogue. First, the structure of the course is discussed. Next, the patients get the opportunity to tell their individual pain histories. (In the 
lessons that follow, no more time is reserved for this.) Afterwards relaxation exercises are introduced. The relaxation training that the patients receive is a kind of progressive relaxation (16). The patients learn to tighten certain groups of muscles and then to relax them, noting in the process the difference in sensation. During each lesson, patients practice together. Eventually, the patient becomes capable of evoking a relaxed feeling in different situations within a very short time. The exercises are to be practiced at home twice a day while listening to a pre-recorded cassette tape. The guest lecturer for the second lesson is a neurologist who gives a layman's explanation of the gate-control theory of pain. The fact is stressed that pain is not solely influenced by physical factors, but also by psychological factors. The gate-control theory is the structure for the rest of the course. In the third lesson, an orthopedic surgeon talks about the structure of the back and about possible causes of back pain. It is hoped that by increasing the patients "knowledge, possible misunderstandings can be cleared up. It is stressed that chronic back pain is often muscle pain, and, by way of a slide presentation, two physiotherapists demonstrate eight exercises that strengthen the muscles of the back and keep the body supple. The patients practice these exercises during the lesson and are asked to do this at home every day. Correct posture is demonstrated by a physiotherapist in the fourth lesson. In addition, general advice is given about foot-wear and sports training. A rehabilitation physician and two ergotherapists present a videotape, in which they discuss how one must treat one's back when performing all kinds of daily activities such as self-care, work, household and leisure activities. Correct posture, as well as a number of daily activities, are practiced with the patients. In this connection, the patients repeat the exercises taught in lesson three under the guidance of the physiotherapist. In the lessons that follow, patients repeat these same exercises with the course instructors. In lesson five, the course instructors discuss the role of psychological factors in mental and physical tension in general and in back pain in particular. Special attention is focused upon what people think about problems and stress and how they cope with them. The patients are encouraged to consider the kind(s) of situation(s) in which they are most troubled by back pain. They are also asked what they think about these situation(s) and how they cope with them. In the sixth lesson, the course instructors discuss the influence of the environment on pain behawior and pain. They point out that pain behavior and pain are often reinforced by positive consequences, such as the attention one gets, the rest one is allowed, and the medication one is given when one is in pain. At the beginning of the last lesson, a number of course evaluation questionnaires are filled out by the patients. The relaxation exercises are then completed. The remaining time is devoted to a general discussion of the structure and content of the course. The patients are encouraged to voice criticisms of the course they have just completed and to make suggestions for courses that may be given in the future. During the refresher lesson eight weeks later, the individual lessons are repeated briefly and some 
Tatule 1. Information and tratining given in the Back School\%.

\begin{tabular}{lll} 
& content & presenters \\
\hline Lesson 1 & pain history & psychologistpedagogue \\
Lesson 2 & pain & neurologist \\
Lesson 3 & back structure/catuses backpain & onthopedic surgeon/physiotherapist \\
Lesson 4 & posture & rehabilitation physician/ergotherapist \\
Lesson 5 & psychological factors & course instructors \\
Lesson 6 & psychological factors & contse instructors \\
Lesson 7 & ewaluation & course instructors \\
Lesson 8 & refresher lesson & course instructors
\end{tabular}

* each lesson includes relaxation exercises \& physical exercises

important implications for dealing with one's back and with the pain in everyday situations are stressed once more. In addition, a follow-up assessment is made at the end of the lesson.

The information and training given in the Back School is summarized in table 1 .

\section{Patients and methods}

\section{Recruitment and selection}

For practical reasons, patients were recruited by means of an advertisement in a local paper, placed one month before the course was planned to start. Within a few days, 106 patients had responded to it. All applicants received a letrer with information regarding the purpose and general content of the course.

The criterium for acceptance into the study was the patients" having had low back pain for at least six months. Exclusion criteria were 1) a medical contra-indication list which specified medical disorders and diseases (e.g. malignity, herniated disc), selected to exclude subjects suspicious of underlying pathology as well as those who were unable to participate in an aerobic exercise program and a relaxation training, 2) a high or very high score on the scale of Rigidity, Distress and Self-satisfaction together (measuring the degree of dogmatism) of the Dutch Personality Questionnaire (17), and 3) a high or very high score on the PSY scale (measuring the degree of psycho-pathology) of the Short Dutch MMPI (18). The psychological screening was done because the Back School is mainly a group education program and, as such, it requires its patients to be open and willing, to some extent, to altemative treatment programs.

In all, 97 patients filled out the lists. After the elimination of 35 patients on the basis of the psychological screening, and of 4 on the basis of the contra-in- 
dication list, 58 patients remained. Lots were drawn and 18 patients were put on a waiting list; the 40 who were left received letters in which they were informed that they were being considered for the course. After receiving the patients" permission, their general practitioners were also informed of the patients" acceptance by the administrators of the Back School.

\section{Design}

Based on the duration of the complaint, patients were divided into a short-duration group ( $0.5-3$ years) and a long-duration group ( $>3$ years). The assumption underlying this prestratification was that patients with a relatively short pain duration should benefit more from the course. After the prestratification the patients were randomly divided into an experimental $(\mathrm{N}=20)$ and a waiting list control group $(\mathrm{N}=20)$. With respect to demographic variables such as age and sex both groups were comparable.

The present study was based on a pretest-posttest-control group design (also called randomised trial) (19), including a follow-up after eight weeks (see figure 1). The experimental group started the course in the first week of September, 1986, the WLC group at the end of October, 1986. The WLC group was, above all, a control group. After the waiting period the WLC group participated in the Back School (experimental period).

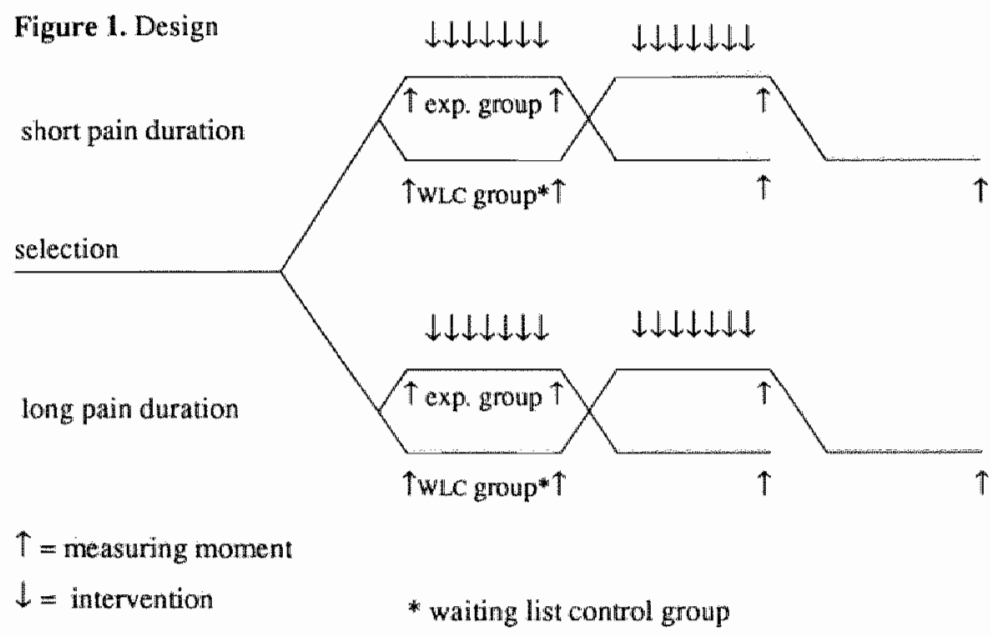

\section{Instruments}

In order to evaluate the course in the beginning (pretest), at the end (posttest), and after eight weeks follow-up, questionnaires were filled out by the patients. Below is a list showing which of the pain-related factors discussed above (environment, 
cognitions, emotions, coping strategy, and activities) were measured by which questionnaire(s), as well as the influence of the pain on daily life and pain intensity.

- West Haven-Yale Multidimensional Pain Inventory (WHYMPI) (20)

This questionnaire consists of 12 factors which can be divided in three components:

- imfluence of pain on daily life (five factors);

- reactions from the environment (three factors);

activities (four factors).

- Pain Cognition List (PCL) (21)

The PCL. was developed for measuring the cognitive component of pain. Factor analysis in a population of back pain patients led to five factors:

- somatic fixation;

- external locus of control;

- intemal locus of control;

- active coping;

- future perspective.

In the PCL the Visual Analogue Scale (VAS) is inserted. This is a line of $10 \mathrm{~cm}$. with "minimum" at one end and "maximum" at the other. On this line one can indicate how much pain one has.

- Zung Self-Judgement Scale for Depression (22)

In this list questions are asked for measuring the degree of depressiveness.

- Utrecht Coping List (UCL) (23)

The UCL measures in what way people react to problems or aversive events, and how they cope with these problems. The list consists of the following factors:

active problem solving;

palliative responses;

waiting/avoiding;

seeking social support;

depressive reaction pattem;

showing emotions;

reassuring thoughts.

- Pain Diary (24)

The Pain Diary is an hourly record, over a period of three days, of 1 ) the activities engaged in and 2) the pain level, expressed in a figure. Zero means no pain; ten means unbearable pain. The measure for up-time is the number of hours of sitting, walking, and standing in the course of one day.

T-tests were used to check whether the scores at the various stages of evaluation differed from one another. The changes resulting from the course in the experimental group were compared with the changes in the WLC group during their 
waiting period by means of gain scores analysis. At the sane time it was analysed whether there were differences between patients with a pain duration of $0.5-3$ years and those with a pain duration of more than 3 years.

\section{Results}

Of the 40 patients who were initially selected for the course, 30 actually completed it. For various reasons 8 patients dropped out before the course began: 2 underwent surgery, 3 had other obligations, 1 left for personal reasons, and 2 for unknown reasons. During the course, 2 patients withdrew because they were too much involved in other activities. The remaining subjects included twelve men and 18 women with an average age of 49.7 years (lower limit 32 years, upper limit 72 years). The educational level of most of the patients was that of vocational school. Eight patients were no longer able to work because of their back pain and, for that reason, they were receiving a state disability benefit. The number of people receiving such benefits would have been higher if housewives had been eligible for them. The results of the program evaluation for the total group, consisting of the experimental group ( $n=16)$ and the WLC group during their experimental period $(n=14)$, are shown in Table 2 .

Comparing posttest results with pretest results for both groups, it was found that the patient's immediate environment reacted less solicitously, which means that the environment reacts in a less concemed way (Environment). With regard to Cognitions, somatic fixation decreased. At the same time, patients were able to cope more actively with their pain. The depression value decreased (Emotions). As far as the Coping strategy was concerned, patients were found to seek less social support and to react in a less depressive way to problems. Of the recorded activities, the household chores increased. Pain seemed to interfere less with daily life and the severity of the pain diminished (Influence of pain on daily life).

Gain scores were obtained by subtracting posttest scores from pretest scores. Results from the experimental group were then compared to scores of the WLC group obtained during their waiting period. In table 3 the results are shown.

It was found that in terms of somatic fixation (Cognitions) and the secking of social support (Coping strategy), the experimental group made more progress. No difference was found between any of the remaining variables. The WLC group, however, increased its internal locus of control (Cognitions) more than the experimental group.

At follow-up ( $n=26$ ) it was found that, compared with the pretest, the environment reacted in a less solicitous way and the distracting responses from the environment had decreased (Environment). With regard to the cognitions, somatic fixation as well as extemal locus of control seemed to have decreased. Patients were also able to cope more actively with their pain. As far as Coping strategy was corcerned, patients were found to seek less social support. Pain 
Table 2. Pretest and postlest scores for Experimental and WLC group ${ }^{+}(N=30)$.

\begin{tabular}{|c|c|c|c|c|c|}
\hline \multirow[b]{2}{*}{ Variables } & \multicolumn{2}{|l|}{ pretest } & \multicolumn{2}{|c|}{ postuest } & \multirow[b]{2}{*}{$\mathrm{T}$} \\
\hline & Mean & s. d. & Mean & s. d. & \\
\hline \multicolumn{6}{|l|}{ Environment } \\
\hline \multicolumn{6}{|l|}{ Reactions from the environment } \\
\hline panishing reponses: & 0.98 & 1.34 & 0.91 & 1.04 & 0.38 \\
\hline Sollicitous responses & 3. 29 & 1.55 & 2.76 & 1.22 & $3.23^{* * *}$ \\
\hline distracting responses & 2.94 & 1. 30 & 2. 64 & 1.37 & 1.32 \\
\hline \multicolumn{6}{|l|}{ Cognitions } \\
\hline somatic fixation & 36.53 & 9.94 & 31.03 & 9.52 & $4.62^{*}$ \\
\hline external locus of control & 20.00 & 6.34 & 18.70 & 6.08 & 1.91 \\
\hline internal locus of control & 24.87 & 5.21 & 25. 23 & 5.77 & -0.66 \\
\hline active coping & 22.77 & 3.95 & 24.63 & 3.40 & -2.74 \\
\hline future perspectives & 20.73 & 4.27 & 20.73 & 3.58 & 0.00 \\
\hline \multicolumn{6}{|l|}{ Eirriotions } \\
\hline depression & 37.53 & 6.55 & 35.33 & 7.40 & $2.75^{* *}$ \\
\hline \multicolumn{6}{|l|}{ Coping strategy } \\
\hline ative problem solwing & 18.53 & 3.16 & 18.57 & 2.94 & -0.08 \\
\hline palliative responses & 20.27 & 4. 28 & 19.50 & 4. 30 & 1.28 \\
\hline wating/avoiding & 15.43 & 3.53 & 15.53 & 3. 74 & -0.19 \\
\hline seeking social support & 12. 60 & 3.05 & 11.17 & 2.67 & 4. $12^{* * 2}$ \\
\hline depiressive reaction pattern & 12.07 & 3.07 & 11.03 & 2.86 & $3.00^{* *}$ \\
\hline showing emotions & 5.90 & 1.97 & 5.63 & 1.56 & 1.00 \\
\hline reassuring thoughts & 13.43 & 2.99 & 13.13 & 2.50 & 0.67 \\
\hline \multicolumn{6}{|l|}{ Activities } \\
\hline up-time & 15.46 & 1. 17 & 15.29 & 1.02 & 0.95 \\
\hline household chores & 3.65 & 1.43 & 3.97 & 1.53 & $-2.37^{*}$ \\
\hline outdoor work & 2.55 & 1.72 & 2. 37 & 1.65 & 0.96 \\
\hline activities away from home & 2.11 & 0.78 & 2.21 & 0.79 & .0 .75 \\
\hline social activities & 2. 98 & 1.02 & 2. 96 & 1. 21 & 0.11 \\
\hline \multicolumn{6}{|l|}{ Influence of pain on daily life } \\
\hline interference & 2. 49 & 1. 34 & 1. 90 & 1.06 & $3.96^{* * *}$ \\
\hline support & 4.37 & 1.62 & 3.91 & 1. 59 & 1.95 \\
\hline pain severity & 2. 49 & 0.86 & 2.02 & 0.85 & 3. $18^{* *}$ \\
\hline self-control & 4.37 & 1. 17 & 4.28 & 1. 44 & 0.29 \\
\hline negative mood & 1.96 & 1. 50 & 1.57 & 1.55 & 1.48 \\
\hline \multicolumn{6}{|l|}{ Pain intensity } \\
\hline VAS & 34.43 & 20.70 & 32.10 & 15.17 & 0.75 \\
\hline pain levell & 2.17 & 1. 60 & 1.90 & 1.52 & 1.30 \\
\hline
\end{tabular}

*P $\mathrm{P} 0.05 ;{ }^{* *} \mathrm{P}<0.01 ; \quad \mathrm{P}<0.001$.

${ }^{+}$Waiting list control (WLC) group during their experimental period. 
Table 3. Comparison of prettest and posttest scores for Experimental and WLC group".

\begin{tabular}{|c|c|c|c|c|c|}
\hline \multirow[b]{2}{*}{ Variables } & \multicolumn{2}{|c|}{$\begin{array}{l}\text { Experimental group } \\
(\mathrm{N}=14)\end{array}$} & \multicolumn{3}{|c|}{$\begin{array}{l}\text { Waiting list control group } \\
(\mathrm{N}=16)\end{array}$} \\
\hline & $\begin{array}{l}\text { pretest } \\
\text { Miean }\end{array}$ & $\begin{array}{l}\text { postrest } \\
\text { Mean }\end{array}$ & $\begin{array}{l}\text { preswest } \\
\text { Mean }\end{array}$ & $\begin{array}{l}\text { posttest } \\
\text { Mean }\end{array}$ & $\mathrm{T}^{4}$ \\
\hline \multicolumn{6}{|l|}{ Environment/ } \\
\hline \multicolumn{6}{|l|}{ Reactions from the environment } \\
\hline solicitous responses & 3. 23 & 2. 56 & 3. 45 & 3. 51 & -1.90 \\
\hline distracting responses & 2.91 & 2. 50 & 2.71 & 3.06 & -1.60 \\
\hline \multicolumn{6}{|l|}{ Cognitions } \\
\hline somatic fixation & 36.00 & 30.07 & 38.94 & 38.24 & -2.46 \\
\hline external locus of control & 19.00 & 17.21 & 22.00 & 21.35 & -0.79 \\
\hline internal locus of control & 23.21 & 22.43 & 24.94 & 26.59 & $-2.62^{* *}$ \\
\hline actiwe coping & 23.00 & 26.64 & 21.88 & 22.35 & 0.89 \\
\hline future perspectives & 20.71 & 20.07 & 21.47 & 20.71 & 0.09 \\
\hline \multicolumn{6}{|l|}{ Emotions } \\
\hline depression & 37.71 & 34.79 & 38.00 & 37.76 & -1.82 \\
\hline \multicolumn{6}{|l|}{ Coping strategy } \\
\hline actiwe problem solving & 18.64 & 18.29 & 18.71 & 18.76 & -0.59 \\
\hline palliative responses & 20.64 & 20.36 & 1.8. 82 & 19.82 & -1.09 \\
\hline waiting/awoiding & 16.07 & 15. 14 & 16. 82 & 15.29 & 0.52 \\
\hline seeking social support & 12. 43 & 10.64 & 12.06 & 12.53 & $-3.02^{* * 1 *}$ \\
\hline depressive reaction pattern & 11.86 & 10.79 & 12.41 & 12. 29 & -1.45 \\
\hline showing emotions & 6.07 & 5.71 & 5.65 & 5.71 & -0.80 \\
\hline reassuring thoughts. & 13.86 & 13.21 & 14.06 & 13.35 & 0.07 \\
\hline \multicolumn{6}{|l|}{ Activities } \\
\hline up time & 15.09 & 15.26 & 15.54 & 15.82 & -0.64 \\
\hline household chores & 3.74 & 4.06 & 3. 54 & 3.64 & 0.65 \\
\hline outdoor work & 2.20 & 2. 19 & 2. 10 & 2.68 & -1.59 \\
\hline activities away from home & 2.20 & 2. 02 & 2. 22 & 2. 12 & -0.26 \\
\hline social activities & 3.18 & 3. 02 & 2.53 & 2. 87 & -1.33 \\
\hline \multicolumn{6}{|l|}{ Influence of pain on daily life } \\
\hline imberference & 2.67 & 2.00 & 2.80 & 2. 48 & -1.07 \\
\hline support & 4.49 & 3.90 & 4. 41 & 4.38 & -1.55 \\
\hline pain severity & 2. 70 & 2.00 & 2.69 & 2.4 .7 & -1.59 \\
\hline self-control & 4.50 & 4.39 & 4. 47 & 4.29 & 0.12 \\
\hline negative nood & 2. 02 & 1.45 & 1.84 & 1.78 & $=0.74$ \\
\hline \multicolumn{6}{|l|}{ Pain intensity } \\
\hline VAS & 38.86 & 28.86 & 41.47 & 31.88 & -0.07 \\
\hline pain level & 2.82 & 2.18 & 1.89 & 1.49 & -0.52 \\
\hline
\end{tabular}

* P<0.05; $P<0.01$.

+ Waiting list control (WLC) group during their waiting period.

T-value of gain scores for both experimental and WLC group. 
seemed to interfere less with daily life and the significant other was less supportive. Also, the severity of the pain had diminished and patients showed a less negative mood (Influence of pain on daily life).

Comparing follow-up ( $n=26$, except for the Pain Dairy $(n=25)$ ) with posttest, it was found that, with the exception of the self-control variable (Influence of pain on daily life), there were no significant differences. Behavior remained stable.

As far as the effectiveness of the Back School is concerned, no difference was found between patients with a pain duration of $0.5-3$ years $(n=14)$ and those with a pain duration of more than 3 years $(n=16)$.

\section{Discussion and recommendations}

\section{Results}

It is difficult to formulate evaluation criteria to determine whether or not the Maastricht Back School can be called a success. How much progress should to be made on a certain variable before a patient notices improvement in his daily life? While it is certainly possible to determine which variables patients show a significant amount of progress on, "statistically significant" does not always mean "clinically relevant", and vice versa. By participating in the Back School, the total group improved significantly on nine variables (see Table 2).

It was found that the experimental group made more progress than the WLC group on two variables. This occurred because the WLC group spontaneously made progress on a number of variables, during the waiting period. The change was significant on two of these variables; internal locus of control (Cognitions) and the VAS (Pain intensity). An observation must be made here. A WLC group cannot be compared with a real control group in that a real control group does not anticipate receiving a certain treatment or guidance. It appears that such control groups show no spontaneous change at all (26). By participating in the Back School, the WLC group made significant progress on seven variables. It appears, then, that offering the course after the waiting period is, indeed, worthwhile. At follow-up after eight weeks, behavior remained stable. The question still remains whether this will also be true after, for example, one year.

The present study revealed no difference between patients with a pain duration of 0.5-3 years and those with a pain duration of more than 3 years. Studies by The Swedish Back School have revealed that the sooner people deal with their backs actively, the better the results are with this program (8). "Dealing with their backs actively", means, among other things, doing exercises, but also studying the role of psychosocial problems. There are those who want to draw the dividing line between acute and chronic pain at two months $(27,28)$. Just how, in concrete terms, the content of the course and the results of the guidance and training would be affected by offering the Back School at an earlier stage is, as yet, unknown. 


\section{Instruments}

Something which is important in determining whether the Back School can be considered a success is the extent to which patients believe in the therapy. Yet; there are no reliable instruments available to measure this (29). Absence during the course, increase in knowledge, and the actual carrying out of the physical and relaxation exercises at home are derived measures. Of the total group, 6 patients were absent once. For practical reasons, the level of knowledge was not measured. One way of judging how often patients exercised at home was to count the number of times this was filled in in the pain diaries, without directly asking to see them. At follow-up, fewer members of the experimental group had filled this in (4 out of 11) than in the WLC group ( 9 out of 14). Frequently after doing the exercises, a decrease in the pain level was reported.

With the exceptions of the UCL (Coping strategy) and the Zung scale (Emotions), the questionnaires used focussed on pain. This shows quite an improvement over the research conducted a few years ago, when there was a demand for instruments to measure pain cognitions and activities (25). The UCL measures dealing with problems or events in general; the subdivision "active coping" (Cognitions) of the PCL specifically measures coping with pain. The WHYMPI and the PCL had not been used before in the Netherlands. The WHYMPI was translated into Dutch especially for this study; the $\mathrm{PCL}$ is still being developed. Little is known about the validity and reliability of these new questionnaires. With regard to the WHYMPI, the Cronbach's Alpha for the sample in this study was .34 for the factor social activities; .59 for the factors negative mood and distracting responses each. For the other remaining nine factors of the WHYMPI, the Cronbach's Alpha ranged from .67 to .85 . For the American version the internal consistency of the factors and the validity have been assessed. Interim surveys have shown satisfying results (20).

Because these questionnaires are so new, it is difficult to compare the results of the Back School with those of other comparable courses. The best comparison that can be made is with the program carried out by the research group at Leiden (7). On the whole, the Leiden results are comparable to those obtained at Maastricht.

From the literature it appears that anxiety has more to do with acute pain than with chronic pain. During the course, however, patients" statements made it clear that anxiety also determines how people with chronic LBP handle physical activities and their back(pain).

Future research would benefit from a somewhat condensed version of the questionnaires used in the present study. It would be desirable to add questions dealing with anxiety and patients' level of knowledge since changing behavior in the intended direction is conditional upon knowing more about the problem itself. 
It was not predicted that the level of pain would decrease; no specific attention was paid to it during the course. Nevertheless, evaluation studies of cognitive-behavioral pain prograns have shown that pain changes as other variables improve. The Back School program probably does not go far enough for it to be able to claim such an outcome. It is also worth mentioning that the two measuring instruments used for subjective pain judgement (Pain intensity) did not change synchronously. The most reliable pain judgement seems to be the pain level, since the calculation of this mean value is based on pain values which are reported every hour for a period of three days. The VAS, by contrast, is noted only once per measuring period.

\section{Recommendations}

By means of education and specific training, a Back School hopes to change the behavior of chronic LBP patients. Therefore, it is necessary to continue analyzing and explaining present-day behavior. In order that the Back School program should meet the needs of chronic LBP patients as closely as possible and, by doing so, perhaps also increase the chances of success, further research on the target group will be necessary in the future. The development of a standard program is recommended. To this end, it would be sensible to design this program in such a way that it would be possible to assess the relative contributions of each component, as well as the effect of being in a group for seven weeks. At the same time, with regard to a cost-benefit analysis, it would be desirable to determine the long-term effects of such programs. Costs include the fees of lecturers and the use of audio-visual equipment; benefits include a decrease in medical consumption and sick-leave.

\section{References}

1 Haanen HCM. Een epidemiologisch onderzoek naar lage rugpijn. Dissertation Erasmus University Rotterdam, 1984.

2 Bywaters ECL. The pathological anatomy of idiopathic low back pain. Irn: American Academy of Orthopaedic Surgeons. Syroposium on Idiopathic Low Back Pain. 1982.

3 Nuchemson A. A critical look at the treatment for low back pain. Scan J Rehab Med $1979 ; 11: 143-147$.

4 "Turk DC, Flor H. Etiological Theories and Treatment for Chronic Back Pain. II. Psychological Models and Interventions. Pain 1984; 19:209-233.

5 Linton SJ. Behavioral Remediation of Chronic Pain: a Status Report. Pain 1986; 24: 125-141.

6 Vlaeyen JWS, Groenman NH, Legrelle T. La douleur chronique et untraitement interdisciplinaire. Rewue de Modification du Comportement. Accepted for publication april 1987. 
7 Spinhoven PH, Linssen ACG. Een gropsprogramma voor patienten thet chronische rugpijn door middel wan educatie en zelfhypose. In: Mattie H, red. Pijnitiformatorium PI 5205:1-7. Alphen aan den Rijn: Stafleu-Samson, 1985.

8 Bergquist-Ullman M, Larson U. Acute Low Back Pain in Industry. Acta Orthopaedica Scandinavica 1977; supplementum no. 170:1-117

9 Melzack, R, Wall, P.D., Pain mechanisms: a new theory. Science, 1965, 150:971-979.

10 International Association for the Study of Pain, Subcommittee on Taxonomy. Pain term: a list with definitions and notes on usage. Pain 1979; 6:249.252.

11 Fordyce WE. Learning Processes in Pain. In: Sternbach RA, red. The Psychology of Pain. New York: Raven Press, 1978.

12. Orlemans JWG, Doesschate RJA ten. Hartziektefobie; een gedragstherapeutisch werkmodel woor behandeling. Huisarts en Wetenschap 1976; 19:323-332.

13 Stembach RA. Clinical Aspects of Pain. In: Sternbach RA, red. The Psychology of Pain. New York: Raven Press, 1978.

14 Willige $G$ van de, Sorbi $M_{n}$ Kluver $R$, Godaert $G$, Schreurs P, Vink I. Gedrag en gezondheid: een interactionele benadering. Gezondheid \& Samenleving 1983:1:32-41.

15 Mayer TG, Gatchel RJ, Kishino N, et al. A Prospective Short-Term Study of Chronic Low Back Pain Patients Utilizing Novel Objective Functional Measurement. Pain 1986: 25: $53-68$,

16 Bernstein DA, Borcovec ThD. Progressive Relaxation Training. A manual for the helping professions. Illinois: Research Press, 1973.

17 Luteijn, F., Starren, J., Dijk, H. van, Handleiding bij de Nederlandse Persoonlijkheids Vragenlijst. Lisse, 1985.

18 Luteijn, F., Kok, A.R., Nederlandse Verkorte MMPI, handleiding Lisse, 1985.

19 Mahoney MJ. Experimental Methods and Outcome Evaluation. Journal of Consulting and Clinical Psychology 1978; 4: 660-672.

20 Kerns RD, Turk DC, Rudy TE. The West Haven-Yale Multidimensional Pain Inventory (WHYMPI). Pain 1985; 23: 345-356.

21 Vlaeyen JWS, Eek H van, Geurts SM, Snijders A, Schuerman JA, Groenman NH. The construction of a Pain Cognition Questionaire. Manuscript in woorbereiding, 1987.

22 Zung WWK. A Self-Rating Depression Scale. Arch. Gen. Psychiat. 1965; 12:63 70.

23 Sichreurs PJG, Willige $\mathrm{G}$ van de. De Utrechtse Copinglijst. Intem Rapport, Vakgroep Klinische Psychologie van de Rijksuniversiteit Utrecht, 1985.

24 Fordyce WE. Behavioral Methods for Chronic Pain and Ilness. Saint Louis: The C.V. Mosby Company, 1976.

25 Stoll DJ. Stress Inoculation Training in the Treatment of Chronic, Intractable, Benign Pain. Academisch Proefschrift Universilty of Louisville, 1984.

26 Kerns RD, Turk DC, Holzman AD, Rudy TE. Comparison of Cognitive Behavional and Behavioral Approaches to the Oupatient Treatment of Chronic Pain. The Clinical Journal of Pain $1.986 ; 1: 195-203$.

27 Schmidt AJM. Persistence Behavior of Chronic Low Back Pain Patients: a medical psychological study. Dissertation University Maastricht, 1986.

28 Lankhorst GJ. In: Commissie Pijn van de Gezondheidsraad. Advies inzalke Pijnbehandeling. "s-Gravenhage, 1986.

29 Jonkers R. Therapietrouw. Vertaling van: Dimatteo MR. Achieving Patient Compliance. Bunnik: Landelijk Centrum Dienstverlening GVO, 1984. 



\title{
| Chapter 4
}

\section{Validity and comparability of studies on the effects of back schools*}

Jolanda F.E.M. Keijsers, Lex M. Bouter \& Ree M. Meertens

* Accepted for publication in Physiotherapy Theory and Practice

\begin{abstract}
In this article studies on the efficacy of back schools are judged on their methodological quality (internal validity) and comparability. All available randomised trials $(n=8)$ were selected for this purpose. The studies were judged on the following criteria: duration and content of the back school, selection criteria and number of patients involved, interventions and measures of effect used. With regard to the internal validity of the studies a number of gaps were found. The numbers of patients involved in the studies were relatively low, no placebo-attention group was used and the principal target of the back schools was not evaluated directly. Because of these gaps it is as yet not possible to formulate a strong and valid judgement on the efficacy of the back schools studied in the trials. In addition to this, the comparability of the studies is rather low. Taken together, the available studies do not suggest back schools to be impressively effective.
\end{abstract}


Low back pain (LBP) is a frequent health problem. In most cases the complaints are self-limiting, with recovery within two or three months in $90 \%$ of cases (Bergquist-Uliman \& Larsson, 1977). Recurrences are frequent (40-60\%) (Haanen, 1984). The complaints are in most cases non-specific, which means that no underlying pathology has been established. In the Netherlands, 8 percent of all consultations with general practitioners involve such non-specific back complaints (Hoekstra, 1985). It is commonly recognized that, in addition to possible physical factors, psychosocial factors are also involved in both etiology and prognosis of low back pain (Meilman, 1984; Nachemson, 1979; Turk \& Flor, 1984). With regard to the duration of the complaint, LBP is usually sub-divided into acute (0-6 weeks), subacute (6-12 weeks) and chronic LBP ( 12 weeks) (Frymoyer, 1988). The majority of patients with acute symptoms are commonly treated using bed rest, analgesic medications, exercises, traction and education. In 10 percent of patients, LBP persists for more than six weeks. In this subacute phase 5 to 10 percent of the patients require an operation because of herniation. With the exception of epidural steroids and braces, non-surgical treatments are similar to treatments given in the acute phase, although the analgesic medication is more specified. After three months of LBP, only 5 percent of the original number of patients still have symptoms (chronic phase). Most patients with chronic LBP benefit to some extent from anti-inflammatory medications and anti-depressants. Exercise programs and educational programs are popular additional treatments in this phase (Frymoyer, 1988).

A promising educational program for back pain complaints is the so-called back school, which is of Swedish origin (Zachrisson Forssell, 1981). Back schools offer an education and skills program in a group setting and consist of a number of lessons (1-16) (Linton \& Kamwendo, 1987). Back schools aim primarily at pain management: information is given about effective ways of dealing with pain, so that the patient will be able to control the pain problem better. Ulimately this is supposed to lead to a decrease in work absenteeism and medical consumption. The purpose of the article presented by Linton \& Kamwendo (1987) was to review and evaluate the empirical literature concerning back schools. They show that most studies that have been conducted lack control conditions. Their conclusion is that the efficacy of back schools is controversial (Fisk ot al., 1983; Linton \& Kamwendo, 1987). In this article the thesis will be defended that this is due to the mediocre methodological quality (internal validity) and the limited comparability of the available studies. For this purpose published studies into the efficacy of a back school, involving a randomly assigned control group (randomised trials) will be discussed here (BergquistUllman \& Larsson, 1977; Berwick et al, 1989; Hurri, 1989; Keijsers et al., 1989; Klaber Moffet et al. 1986; Lankhorst et al, 1983; Postacchini et al., 1988; Stankovic \& Johnell, 1990). The reason for excluding other types of studies is that the results of these studies are hardly interpretable. Furthermore, this review deals with non-clinical back schools in a group setting only. Individualized back 
schools such as that reported on by Lindequist et at. (1984), and clinical rehabilitation programs, such as that published by Aberg (1984) are left out for the sake of homogeneity.

The first section of this paper presents the methodological criteria by which we judged the studies. After that, the randomised trials are discussed critically with regard to these criteria (internal validity), and it is argued to what extent studies on the efficacy of back schools are comparable. The article ends with a discussion of the claims on the effectiveness of the back school stated in the available randomised trials. Furthermore, some recommendations for future research on the efficacy of back schools will be formulated.

\section{Criteria}

There is a reasonable degree of consensus on methodological requirements for randomised trials (Pocock, 1983). For an overall statement about the efficacy of back schools, it is not only the internal validity of the individual studies which is important, but also the comparability of the studies. Questions related to the latter include whether the interventions, patients and effect parameters of the individual studies are sufficiently similar. This does not mean that the studies need to be fully identical on these points. If differences between the studies exist, it should be argued to what extent they will have an important prognostic influence on the effect of the intervention. In the present study, research on the efficacy of back schools was assessed on the following criteria.

1. Duration and content of the back school.

How many lessons does the back school consist of, and which information and/or training is given?

2. Selection criteria and numbers of patients involved.

Which patients are included and which patients excluded, and how many patients are recruited for the study?

3. Interventions and execution of the study.

Which interventions are compared and are there long-tern follow-up measurements?

4. Effect parameters.

Which effect parameters are used to assess the efficacy of the back school?

\section{Duration and content of the back school}

The back school developed by Zachrisson Forssell (1981) consists of four mainly audio-visual lessons. In these lessons the physical factors influencing back complaints are pointed out. Little time is available for exercises (Zachrisson Forssell, 


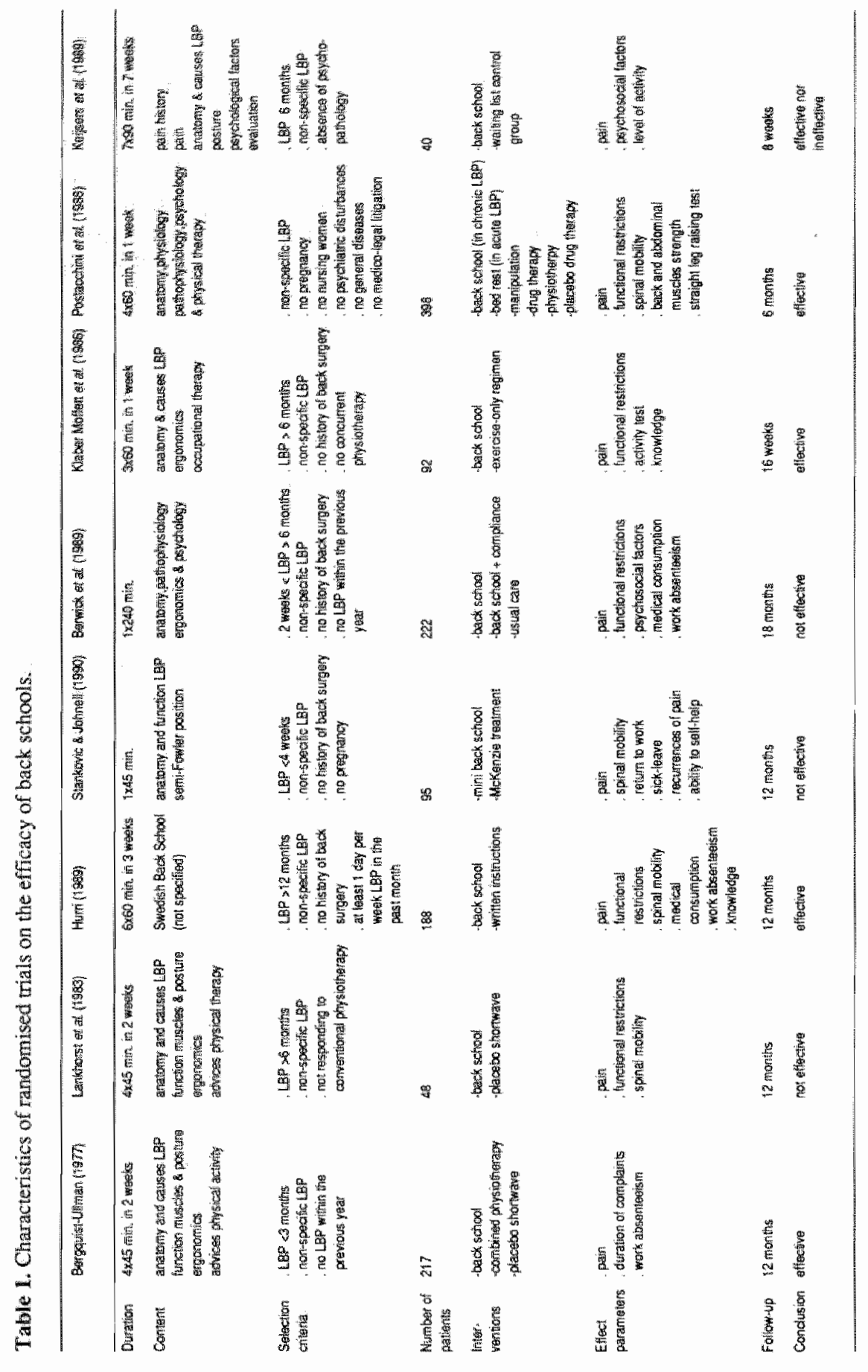


1980). In Table 1 the available trials are based upon similarities in content and duration of the back schools arranged. It shows that the back schools in the several studies differ substantially.

The articles by Bergquist-Ullman \& Larsson (1977), Lankhorst et al. (1983) and Hurri (1989) deal with versions of the Swedish back school. With respect to the duration of these back schools it appears that the Swedish back school presented by Hurri (1989) differs substantially from the original Swedish back school designed by Zachrisson Forssell (1981). The back school reported on by Klaber Moffett et. al (1986), as well as the Swedish back school, are characterized by a mainly physical approach of the pain problem. However, compared to the Swedish back school, the back school reported on by Klaber Moffett $e t$ al. pays more attention to the practical application of the information given. The back school of Berwick et al. (1989) consists of a single 4-hour session during which subjects such as the anatomy, pathophysiology, ergonomics, and psychology of back pain complaints are discussed. The mini back school presented by Stankovic \& Johnell (1990) consists of a single session of 45 minutes in which the anatomy and function of the back are explained. Patients in this back school were adviced to refrain from exercise but lie supine in the semi-Fowler position several times per day, but to keep on the move during the day in order to avoid inactivity syndrome.

The back school presented by Postacchini et al. (1988) is based on the model of the Canadian Back Education Unit (Hall, 1980). In the Maastricht back school developed by Keijsers et al. (1989) a much wider range of possible factors influencing low back pain is discussed. The Maastricht back school consists of seven lessons and approaches pain in a multidimensional way: in addition to physical factors attention is given to the psychosocial factors influencing LBP. Furthermore, exercises that strengthen the back and abdominal muscles and relaxation exercises are performed during the lessons.

\section{Selection criteria and numbers of patients involved}

Three studies included employees with LBP (Bergquist-Ullman \& Larsson, 1977; Hurri; 1989; Stankovic \& Johnell, 1990). Contrary to the studies of BergquistUllman \& Larsson and Hurri, in the randomised trial of Stankovic \& Johnell (1990) the employees involved were not from one specific company. All studies included patients suffering from non-specific LBP. However, what is defined as non-specific LBP in one study is sometimes defined as specific LBP in another study. In the study presented by Lankhorst et al. (1983), for example, a scoliosis of more than 15 degrees was an exclusion criterion, which was not the case in the seven other studies. Four out of the eight studies were restricted to a pain duration of more than six months; three were restricted to a pain duration of less than six months. In the study presented by Postacchini et al. (1988), patients with (sub)- 
acute as well as chronic low back pain were admitted. Klaber Moffett et al. (1986), Stankovic \& Johnell (1990), Hurri (1989) and Berwick et al. (1989) excluded patients with a prior history of back surgery. In the studies presented by Stankovic \& Johnell (1990) and Postacchini et al. (1988) pregnant women were also excluded. Klaber Moffett et al. (1986) excluded patients concurrently attending physiotherapy treatment as well. Hurri (1989) included patients with LBP symptoms on at least one day each week during the month preceding the initial examination. Lankhorst et al. (1983) used the inclusion criterium of not responding to conventional physiotherapy; Bergquist-Ullman \& Larsson (1977) as well as Berwick et al. (1989) required a pain-free year before onset of the current episode of LBP. In the studies reported on by Postacchini et al. (1988) and Keijsers et al. (1989) patients were excluded when there was evidence of some psychological or psychiatric morbidity. Postacchini et al. (1988) also excluded patients with serious general diseases or when medico-legal litigation was pending.

Because of the various selection criteria used, it is not easy to interpret, compare and generalize the results of the eight available randomised trials. Even when identical back school programs were offered, there would still be some pitfalls. For example, the studies by Bergquist-Ullman \& Larsson (1977) and Lankhorst et al. (1983), involve a spectrum of patients that does not even overlap to some extent. In principle, all differences in selection criteria used could be responsible for the differences in the effects found.

The numbers of patients were small in most studies. Hence, only a relatively large difference between the experimental group and the control group on the effect parameters will be statistically significant. In his review, Grahame (1980) points out that a minimum of 100 patients per group is needed in order to achieve statistical confirmation of trends showing differences between the groups. Only in the studies of Bergquist-Ullman \& Larsson (1977), Berwick et al. (1989) and Hurri (1989) was this minimum of 100 patients per group approximated.

\section{Interventions and execution of the study}

In all studies patients were randomly assigned to either a back school group or a control group. Whether the control group received any intervention and if so what kind of intervention, is shown in table 1. One study used a waiting list control group, meaning that after a period of waiting, the control group was admitted to the back school course. In two studies on the efficacy of the Swedish back school a placebo group received detuned shortwave applications to the back (BergquistUltman \& Larsson, 1977; Lankhorst et al., 1983). Beside a placebo group, Bergquist-Ullman \& Larsson (1977) formed a group receiving physiotherapy. In the study presented by Postacchini $e t$ al. (1988) patients were randomly assigned to either manipulation, drug therapy, physiotherapy, bed rest (only in acute LBP), 
back school (only in chronic LBP) or placebo drug treatment. In the study presented by Hurri (1989), the patients in the control group were given the instruction material of the back school in a written form. Klaber Moffett et al. (1986) compared the back school group with a group of LBP patients receiving an exercise-only regimen. The mini back school group of Stankovic \& Johnell (1990) was compared to a group receiving McKenzie method of treatment. In the study by Berwick et al. (1989) the back school group was compared with a group which, in addition to back school treatment, received a "compliance package" program, designed to encourage appropriate self-management for back pain, and with another group receiving the usual care for their back pain.

Research on the efficacy of back schools has to take into account the role of non-specific effects of the treatment. Participation in a back school program, for example, could lead to an improvement unrelated to the specific content of the program. Including placebo treatment in the study design provides insight into these non-specific effects. A placebo treatment is a treatment which cannot be distinguished externally from the experimental treatment, but in which the supposed active component is left out. For the back school this means that placebo treatment would consist of a number of group sessions in which the supposed active components (education and training) are left out. This is called a placeboattention group and could be realized by organizing a self-help group. In research on the efficacy of back schools detuned shortwave application and drug therapy have been used as a placebo (Bergquist-Ulman \& Larsson, 1977; Lankhorst et al., 1983; Postacchini et al., 1988). The value of these placebo treatments is questionable. Research involving no placebo compares different treatment strategies. The question is then which treatment has the greatest effect and not what the difference is between the specific and the non-specific effect of the treatment. Such studies are called pragmatic trials. The so-called explanatory trial (including a placebo group) allows the detection of a possible difference between the specific and the non-specific effect of the treatment. The study presented by Bergquist-Ullman \& Larsson (1977) used a combination of both types of design. On the one hand a comparison was made between back school treatment and physiotherapy, while on the other hand a placebo treatment was used to study the effects of the supposed active component of back school treatment and of physiotherapy treatment.

It is an inherent feature of randomised trials that patients are randomly assigned to back school treatment or to the comparison group(s). The randomisation, however, is not always performed properly. In the study presented by Lankhorst et al. (1983), the first six consecutive patients entered the experimental group, the 2nd and 3rd sextets the control group, and so on. The results of this study could be biased due to the fact that the first six patients were perhaps not fully comparable to the second six patients. The reasons for dropping out were seldom mentioned in the studies. An effect could, however, be biased because of a selective drop out. In the studies reported on by Bergquist-Ulliman \& Larsson 
(1977), Lankhorst et al. (1983), Hurri (1989), Berwick et al. (1989) and Stankovic \& Johnell (1990) measurements were made to determine the long-term effects of the back school one year or more after the intervention.

\section{Effect parameters}

Pain is difficult to measure. It encompasses subjective, physiological and behavioural aspects. This diversity is not always sufficiently reflected in the effect parameters used. What is measured in order to determine the efficacy of back schools is summarized in table 1. Although a decrease in pain intensity is rarely mentioned as a main objective of the back school, it plays an important role in its assessment (Guck, 1984). Klaber Moffett et al. (1986), Lankhorst et al. (1983), Postacchini et al. (1988) as well as Stankovic \& Johnell (1990) measured only pain intensity. In the study of Postacchini et al. (1988) this is not only assessed by the patients but also by the physician. Linton \& Kamwendo (1987) concluded in their review that a decrease in pain intensity cannot be expected from a back school program. The operationalisation of pain in the studies by BergquistUllman \& Larsson (1977), Keijsers et al. (1.989), Hurri (1989) and Berwick et al. (1989) consisted of measuring the multidimensional aspects of pain.

The degree of disability as a result of back pain (functional restrictions) was measured by Klaber Moffett et al. (1986), Lankhorst et al. (1983), Berwick et al. (1989), Hurri (1989), and Postacchini et al. (1988). In the study by Klaber Moffett et al. (1986) this was extended with an observation of activities. Lankhorst $e t$ al. (1983), Hurri (1989), Postacchini et al. (1988) and Stankovic \& Johnell (1990) measured spinal mobility. Keijsers et al. (1989) used a so-called pain diary, enabling them to make a statement about the degree of disability: a low level of activity was equivalent to a high level of disability. In summary, it appears that in six of the eight studies the degree of disability was an effect parameter.

Psychosocial factors influencing pain were measured by Keijsers et al. (1989) and Berwick et al. (1989), while levels of knowledge on subjects related to back pain were measured by Klaber Moffett et al. (1986) and Hurri (1989) only. Bergquist-Ullman \& Larsson (1977) measured the duration of symptoms expressed as numbers of days from the start of the treatment. In addition, BergquistUllman \& Larsson (1977), Berwick et al. (1989), Hurri (1989) and Stankovic \& Johnell (1990) measured absenteeism from work, which is important with regard to a cost-benefit analysis of the back school. In the study reported on by Stankovic \& Johnell the mean duration before returning to work as well as the number of recurrences of $L B P$ were measured.

It is remarkable that the central goal of the back school (pain management) was not measured directly. In the study presented by Stankovic \& Johnell (1990) patients' ability to self-help was measured. From the article it is not clear whether this is similar to pain management. In most studies a number of factors which 
have to do with pain (for example activity level) formed the variables by which the efficacy of the back school is assessed. The implicit assumption at the basis of this practice is that an improvement in for example an activity list indicates that a patient is better able to manage the pain. However, it is possible that a patient is able to manage the pain without showing a corresponding improvement in activity level. It would therefore be preferable to measure pain management directly. The concept of self-efficacy offers a theoretical basis for this (Bandura, 1977). Perceived self-efficacy refers to people's judgments of their capabilities to execute a certain behaviour. The role of self-efficacy in the management of pain has been demonstrated in several studies (Council et al., 1988; O'Leary, 1985). Self-efficacy in managing pain can be seen as a common factor underlying cognitive and affective influences on pain experience. Research has shown that self-efficacious patients are more inclined to manage their pain with the help of non-medical strategies (O'Leary, 1985). Based on the theory of self-efficacy, pain management could be measured in the following way. The patient is asked whether he is capable of managing his back pain in a number of pain-related situations. In this way, information regarding the target of pain management is provided directly by the patient himself.

With regard to the questionnaires used, it is remarkable that most questionnaires were not standardized and that they were developed for a single study only. This was especially the case for the questionnaires inquiring about medical consumption and work absenteeism. This lack of standardization means that the validity and reliability of the questionnaires are in most instances unknown. Consequently, the comparability of the data collected by means of these questionnaires is doubtful.

\section{Discussion}

Pain was operationalized in all studies. The study by Bergquist-Ullman \& Larsson (1977) suggests that the Swedish back school is an effective means of pain management for acute and subacute LBP patients. Lankhorst et al. (1983) could not demonstrate any effect of thị Swedish back school on pain in chronic LBP patients. In the studies reported on by Postacchini et al. (1988), Klaber Moffett et al. (1986) and Hurri (1989) it was concluded that for chronic LBP patients the back school is effective for the effect parameter pain. This conclusion in the latter study, however, was only supported by the data at six months follow-up. At 12 months follow-up the effect of the back school on pain appeared to have faded away. The effect on pain of the back school presented by Berwick et al. (1989) and Stankovic \& Johnell (1990), both consisting of a single session, seems to be small for (sub)acute LBP. The results of a pilot study presented by Keijsers et al. (1989) on pain could not confirm nor refute the supposed positive effect of the back school. 
Internal validity as well as comparability are important factors in an overall judgement on the efficacy of the back school. With regard to the intemal validity, the following gaps were found. The numbers of patients inwolved in the studies were relatively small and the randomisation was not always executed properly. None of the studies made use of a placebo-attention group and the main target of the back school was never evaluated directly. Because of these methodological problems it is as yet not possible to formulate a valid judgement on the efficacy of the back schools studied in the available trials. The studies by Berwick et al. (1989), Bergquitst-Ullman \& Larsson (1977) and Hurri (1989) seem to be the most informative. These studies involved a relatively large number of patients; they determined the long-term effect of the back school and they measured work absenteeism and medical consumption, so that a cost-benefit analysis could be mate. Of the back schools assessed in these three studies, at 12 months follow-up only that of Bergquist-Uliman \& Larsson (1977) was found to be effective. A back school consisting of a single four hour session of instruction was clearly ineffective (Berwick et al., 1989).

The problems concerning the intemal validity of the studies impair the comparability of the studies as well. In addition to this, the selection criteria appeared to vary a good deal. This would not be a problem if the differences found in the criteria had no influence on the effect, but they often have. Two studies are probably hardly comparable if, for example, selection is based on psychological variables in one study and not in the other. It is oftem assumed that the presence or absence of certain psychological characteristics has a prognostic influence on the effect of the intervention. In addition, criteria which sound similar need also some critical attention. The criterion non-specific LBP, for example, turned out to be multi-interpretable. The same is true for the different contents of back schools. Back schools in which no attention is paid to the execution of exercises during the lessons are hardly comparable to back schools in which such exercises are practised during the lessons. The studies presented by Bergquist-Ullman \& Larsson (1977) and Hurri (1989) investigated the efficacy of a Swedish-type back school. Nevertheless, these studies are hardly comparable. because of the different selection criteria used. Patients with a pain duration of 12 months or more are probably not comparable to patients with a pain duration of less than three months.

Future research on the efficacy of back schools will have to guarantee both the internal validity and comparability. With regard to internal validity this means that, for example, the randomised trial should include sufficient numbers of patients and that pain management should be measured directly. The comparability can be increased by preventing differences in interventions and patients between the various studies. This means that questions such as which patients are to be admitted should be taken very seriously. A certain degree of consensus about the central issues seems desirable. Such a consensus will increase the compara- 
bility of studies on the efficacy of back schools. Standardisation of issues with regard to both the internal validity and comparability would improve justification of conclusions within trials as well as between trials.

\section{References}

Aberg J 1984 Evaluation of an advanced back pain rehabilitation program. Spine 9:317-318. Bandura A. 1977 Social Learning Theory. Englewood Cliffs: Prentice Hall

Bergquist-Ullman M, Larsson U 1977 Acue Low Back Pain in Industry. Acta Orthopaedica Scandinavica (suppl) 170: 1-117.

Berwick D M, Badman S, Feldstein M 1989 No Clinical Effect of Back Schools in an HMO, A Randomized Prospective Trial. Spine 14: 339-344.

Council J R, Ahern D K, Follick M J, Kline C L 1988 Expectancies and functional impairment in chronic low back pain. Pain 33: 323-331.

Fisk J R, DiMonte P, McKay Courington S 1983 Back Schools, Past, Present, and Future. Clinical Orthopaedics and Related Research 179: 18-23.

Frymoyer J W 1988 Back pain and sciatica. The New England Journal of Medicine 318 : $291-300$.

Grahame R 1980 Clinical Trials in Low Back Pain. Clinics in Rheumatic Diseases 6: 60-63.

Guck T P 1984 Stress Management for Chronic Pain Patients. The Journal of Orthopaedic and Sports Physical Therapy 6:5-7.

Haanen H C M 1984 Een epidemiologisch onderzoek naar lage rugpijn. Dissertation Erasmus University Rotterdam.

Hall H 1980 The Canadian Back Education Units. Physiotherapy 66: 115-117.

Hoekstra G R 1985 De rugpijnpatiënt in de huisartspraktijk. In: Kingma M J, Dokter H J (red): Rugpijn. Utrecht: Bohn, Scheltema \& Holkema, p40-66.

Hurri H 1989 The Swedish Back School in chronic low back pain. Part I. Benefits. Scandinavian Journal of Rehabilitation Medicine 21: 33-40.

Keijsers J F E M, Groenman N H, Gerards F M, van Oudheusden E, Steenbakkers W H L 1989 A Back School in the Netherlands: Evaluating the Results. Patient Education and Counseling 14: 31-44.

Klaber Moffett J A, Chase S M, Portek I, Ennis J R 1986 A controlled, prospec tive study to evaluate the effectiveness of a back school in the relief of chronic low back pain. Spine 11: $120-122$.

Lankhorst G J, van de Stadt R J, Vogelaar T W, van der Korst J K, Prevo A J H 1983 The effect of the Swedisch Back school in chronic idiopathic low back pain. Scandinavian Journal of Rehabilitation Medicine 15: 141-145.

Lindequist S L, Lundberg B, Wikmark R, Bergstad B, Loof G, Ottermark A C 1984 Information and regime at low back pain. Scandinavian Journal of Rehabili tation Medlicine 16: 113-116.

Linton S J, Kamwendo K 1987 Low Back Schools, A Critical Review. Physical Therapy 67: 1375-1383.

Meilman PW 1984 The management of the chronic pain patient: clinical considerations. The Journal of Orthopaedic and Sport Physical Therapy 5: 305-31.7.

Nachemson A 1979 A critical look at the treatment for low back pain. Scandinavian Journal of Rehabilitation Medicine 11: 143-147.

O'Leary A 1985 Self-efficacy and Health. Behaviour Research and Therapy 23: 437-451.

Pocock S J 1983 Clinical Trials, a Practical Approach, Chichester. 
Postacchini $F$, Fachini M, Palier 1988 Efficacy of warious forms of conservative treatment in low back pain, A comparatiwe study. Neuro-Orthopedics 6:28-35.

Stankovic R, Johnell 01990 Conservative treatment of acute low back pain, A prospective randomized trial: Mckenzie nethod of treatment versus patient education in "mini back school ${ }^{*}$. Spine 15:120-123.

Turk D C, Flor H 1984 Etiological Theories and Treatment for Chronic Back Pain II. Pychological Models and Interventions. Pain 19: 209-233.

Zachrisson Forssell M1980 The Swedisch Back School. Physiotherapy 66: 112-114.

Zachrisson Forssell M 1981 The Back School. Spine 6: 104-106. 


\title{
Chapter 5
}

\section{The efficacy of the back school}

\section{A randomized trial ${ }^{*}$}

Jolanda F.E.M. Keijsers, Mieke W.H.L. Steenbakkers, Ree M. Meertens, Lex M. Bouter \& Gerjo Kok

* Published in Arthritis Care and Research 1990; 3: 204-209

\begin{abstract}
Although the back school is a popular treatment for patients with low back pain, especially in Scandinavian countries, very few well-designed studies into the effectiveness of this type of treatment have been performed. Back schools are programs in a group setting, directed towards pain management, consisting of elements of education and/or training of skills. The Maastricht Back School is designed to be a combination of all those elements about which we consider that a back school should give information and training. In order to determine the effectiveness of the Maastricht Back School, we conducted a randomized controlled trial $(\mathrm{N}=77)$ comparing a back school group with a waiting list control group. The most important measures of effect were: pain management, pain, medical consumption and absenteeism from work. The overall response was $85.5 \%$. The results of an intention-to-treat analysis of the data collected two and six months after randomization consistently suggested inefficacy of the Maastricht Back School for all effect parameters (except for the effect parameter knowledge). Though the present study certainly had some limitations, we may consider back schools to have no clinically relevant effects.
\end{abstract}




\section{Introduction}

Onde of the possible treatments for patients suffering from low back pain is the sowcalled back school, which is of Swedish origin $(3,11)$. Back schools offer an education and skills program in a group setting (10-12 patients per group) and primarily aim at pair management: information is given about ways of dealing with pain, so that the patient is able to control his pain problem more effectively (7). Although the back school is a popular treatment for patients suffering from low back pain, the results of the few well-designed studies into the effectiveness of this treatment indicate at most borderline effects for the back school (4). It is postulated that patients with not yet a chronic pain problem could benefit more from back school treatment (6).

The Maastricht Back School consists of seven sessions, each lasting 2.5 hours, plus a refresher session after 6 months. A course instructor is present at every session. In addition, various guest lecturers are invited to give information and training. As was pointed out in another article by Keijsers et al., the Maastricht Back School approaches pain in a multidimensional way, which is generally accepted to be a desirable method (4). The Maastricht Back School is designed to be a combination of all elements about which we consider that a back school should give information and/or training. In order to investigate the effectiveness of the Maastricht Back School, we conducted a randomized trial in primary health care, comparing a group receiving the Maastricht Back School treatment with a waiting list control group. Patients in the waiting list control group were promised back school treatment at the end of the study. If the Maastricht Back School tums out to be effective, it will be implemented in Dutch out-patient care. This implies that up till now the Maastricht Back School does not form a part of the primary health care system and that it was initially developed for the research project.

After presenting the inclusion and exclusion criteria and the effect parameters, this article describes the statistical methods of data analysis. Next, the principal results of the evaluation study are presented. Finally, results and validity of the study are discussed.

\section{Selection of patients}

The inclusion criteria for the study required the presence of low back pain for at least two months, with a maximum of three years. Criteria for exclusion were suspicion of underlying pathology (e.g. malignity, herniated disc) as well as being unable to participate in a physical exercise program and a relaxation training (since these are essential parts of the Maastricht Back School). Prospective participants were judged on all these criteria by the general practitioners recruiting the study population. With permission of the eligible patients, the general 
practitioners sent their names and addresses to the Department of Health Education. We further informed them about the Maastricht back school and the design of the study. Patients who then signed the informed consent form were given a number. The randomization was performed by in turn assigning these numbers to either the experimental or the control condition.

\section{Effect parameters}

The most important effect parameters in this study were 1) pain management; 2) pain, measured by a) the West Haven-Yale Multidemensional Pain Inventory (WHYMPI), sub-divided into influence of pain on daily life, reactions from the environment and activities (5) and b) a Visual Analogue Scale (VAS) (10); 3) medical consumption, sub-divided into consultations with health care providers, treatments and medicine taking; and 4) absenteeism from work. Pain and pain management were both measured by a visual analogue scale. For pain the anchor words were "no pain" and "much pain"; for pain management "not able to manage the pain" and "very much able to manage the pain". The number of consultations with health care providers was determined by adding the frequencies of consultations with a general practitioner, a physical or manual therapist, al specialist or some alternative physician. The number of treatments were determined by adding the number of common methods of treatments for low back pain patients. Medicine taking was computed by adding the number of types of medicine usually prescribed for low back pain. Absenteeism from work was expressed in number of days. Other outcome measures were functional restrictions (measured by the Sickness Impact Profile (1)), knowledge of the subjects discussed in the course, general well-being and satisfaction. General well-being as well as satisfaction with the Maastricht Back School was measured by a visual analogue scale. For general well-being the anchor words were "feeling very bad" and "feeling very well"; for satisfaction with the course "very dissatisfied" and "very satisfied".

Data on these parameters were collected at baseline, and two and six months after randomization. All information was gathered by way of questionnaires, filled out by the patients. Table 1 shows the schedule of data collection. 
Table 1. Dota collection sehedule.

\begin{tabular}{llll}
\hline instrument & baseline & 2 moniths & 6 months \\
\hline pain mantagement & $\mathrm{X}$ & $\mathrm{X}$ & $\mathrm{X}$ \\
pain (WHYMPI) & $\mathrm{X}$ & $\mathrm{X}$ & $\mathrm{X}$ \\
pain (VAS) & $\mathrm{X}$ & $\mathrm{X}$ & $\mathrm{X}$ \\
medical consumption & $\mathrm{X}$ & & $\mathrm{X}$ \\
work absenteism & $\mathrm{X}$ & & $\mathrm{X}$ \\
functional restrictions (SIP) & $\mathrm{X}$ & & $\mathrm{X}$ \\
knowledge & & $\mathrm{X}$ & $\mathrm{X}$ \\
general well being & $\mathrm{X}$ & $\mathrm{X}$ & $\mathrm{X}$ \\
satisfaction & & & $\mathrm{X}$ \\
\hline
\end{tabular}

\section{Statistical methods}

In order to examine the effect of the Maastricht Back School, we performed univariate analyses of variance (ANOVAs) and, if there was more than one dependent variable, multiwariate analyses of variance (MANOVAs) of the repeated measures data (also called mixed between-within-subjects MANOVA, split plot or randomized block factorial design), using the SPSS-X package (8). The independent variables were "condition", with two levels (experimental and control group), and "time", with three levels (baseline, two months after randomization, and six months after randomisation). The ANOVA and MANOVA repeated measures techniques provided a general test of whether groups with and without Maastricht Back School treatment differed over time for the effect parameter at issue. In other words, the ANOVA and MANOVA repeated measures tested: 1) the difference between the two treatment groups without considering levels of time (effect of condition), 2) the difference in time without considering levels of condition (effect of time) and 3) the difference across time between the two treatment groups (effect of interaction, i.e. the effect of condition $x$ time). If the effect of interaction is significant this indicates that one type of treatment (Maastricht back school or waiting list control) "works best". Hence, the effect of interaction gives us information about the main research question, which was: is there a difference in effect between a group receiving back school ireatment and a waiting list control group? An alternative to analysis of variance of the repeated measures data would have been a separate analysis for each moment of data collection and for each dependent variable. However, due to the number of effect parameters, this would lead to an excessive number of significance tests and thus to chance capitalizing. The results of an evaluation of the main assumptions of ANOVA and MANOVA (9) were satisfactory. 
Furthermore, univariate analyses of covariance (ANCOVAs) and multivariate analyses of covariance (MANCOVAs) of the repeated measures data were performed on most of the dependent wariables, in order to determine the effectiveness of the Maastricht Back School after adjustment for differences between the groups in baseline scores, pain duration, cause of the pain, sex, level of education and age. These covariates were used because they were found to correlate strongly with most dependent variables (Pearson correlation coefficients). If in an ANCOVA or MANCOVA the effect of interaction is significant, this indicates that after adjustment for the covariate (such as baseline scores) one type of treatment "works best". The results of an evaluation of the main assumptions of ANCOVA and MANCOVA (9) were satisfactory.

\section{Results}

Of the 96 patients who applied for the Maastricht Back School, six were not willing to sign the informed consent form. Of the remaining 90 patients, 13 dropped out (defined as not filling out the questionnaires at all three noments of data collection); these were six patients of the experimental group and seven of the waiting list control group. The main reasons for not completing the trial were of a practical (e.g. an operation on a patient's knee) or private nature (e.g. illness of a family member). Six out of the 13 drop outs were lost at the first moment of data collection. Therefore no baseline data are available for these six drop outs. The remaining seven patients dropped out at either the second or third moment of data collection. The mean age of these seven patients who were all men was 42.1 years, and they had an average pain duration of 9.8 years.

The patients included 39 men and 38 women, with a mean age of 35.8 years. Although the general practitioners selected on pain duration, we inquired after patients' pain duration. The average pain duration was 7.5 years, which is not in accordance with the inclusion criterium of low back pain for at least two months, with a maximum of three years. The educational level of most of the patients was that of vocational school. 44 Patients had at the time of the study a fulltime or partime job. Due to their back pain, 14 patients received a state disability benefint. Compared to the waiting list control group the experimental group included more women (14 in the experimental group; 24 in the waiting list control group) and more patients receiving a state disability benefit (11 in the experimental group; 3 in the waiting list control group). Furthermore, the educational level in the experimental group was lower. For all other demographic variables no meaningfull differences between the experimental and waiting list control group were found. As shown by the means presented in table IIB, at baseline both groups differed substantially on almost all effect parameters used.

In order to explain in detail the procedure of data analysis, the effect of the Maastricht Back School on medicine taking (a sub-division of the medical 
consumption) is presented by way of example. Data on other effect parameters were andysed in exactly the same way. Because the findings were consistent. they are not discussed in detail for all effect parameters.

Patients were asked about their medicine taking at baseline and six months after randomization. They were asked what medication they had been using for their back pain during the last six months. Medicine taking per patient was then calculated by counting the types of medicine (for example tranquilizers) they used. The maximum number of types was seven. If a patient used all types of medicine, the score was seven; if a patient used none of them the score was zero. Step one of the general procedure followed consisted of an analysis of the calculated means. The means of each data collection for the experimental group and the waiting list control group are presented graphically in figure 1.

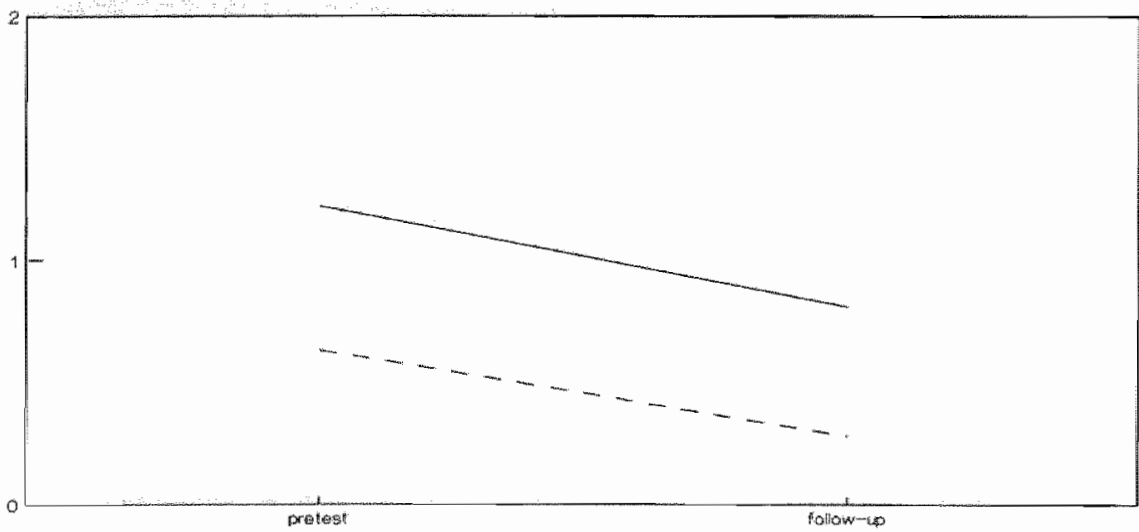

Figure 1. Means for data on medicine taking at baseline and 6 months follow-up.

Given the random procedure, it is some what surprising that the means for the experimental and the waiting list control groups already differed substantially at baseline (at-test between the groups showed that this difference was statistically significant at $p=.031)$. Six months after randomization the means for the two groups still differed substantially. The next step, which was the most interesting one with regard to the central question of the study, was to find out whether the change in the experimental group was larger than that in the waiting list control group. This effect of interaction turned out not to be statistically significant $(\mathrm{d} f=1,75, \mathrm{f}=.079, \mathrm{p}=.779)$; the effects of time $(\mathrm{df}=1,75 \mathrm{~F}=14.68 \mathrm{p}=.001)$ and condition $(\mathrm{df}=1,75 \mathrm{~F}=11.84 \mathrm{p}=.001)$, however, were significant. This indicates 
that with regard to medicine taking, there was no difference between the back school group and the waiting list control group. Looking again at figure 1, it can be seen that the two groups differed over time (the effect of time) and that the means for the experimental group differed from those for the waiting list control group (the effect of condition). With regard to medicine taking, the gain for the experimental group was not larger than the gain for the waiting list control group (effect of interaction).

This same procedure was carried out for all effect parameters. Because the results were in general similar for all measures of effect, they are not discussed in detail. Instead the effects of interaction for the effect parameters are presented, because these are the most interesting ones with regard to the research question. Table $2 \mathrm{~A}$ summarizes these effects of interaction. It shows that there are no significant effects of interaction. In Table $2 \mathrm{~B}$ the corresponding means for the experimental and control groups are given for each data collection and effect parameter.

Table 2A. Test statistics from MANOVA repeated measures for the interaction effects condition $x$ time for the effect parameters.

\begin{tabular}{|c|c|c|c|}
\hline Effect parameters & $\mathrm{F}$ & df. & P-value \\
\hline Pain management & 2.21 & 2,71 & .12 \\
\hline Pain (WHYMPI) & .91 & 12,64 & .59 \\
\hline $\operatorname{Pain}(\mathrm{VAS})$ & 1.32 & 2,73 & 27 \\
\hline \multicolumn{4}{|l|}{ Medical consumption } \\
\hline -consultations & .36 & 5,58 & .87 \\
\hline treatments & 1. 32 & 16,60 & .22 \\
\hline -medicine taking & .08 & 1,75 & .78 \\
\hline Work absenteeism & .56 & 1,42 & .46 \\
\hline Functional restrictions (SIP) & 1.33 & 2,74 & .27 \\
\hline General well-being & 1.05 & 2,70 & .36 \\
\hline
\end{tabular}

Univariate and multivariate analyses of covariance for the repeated measures data did not reveal significant effects of interaction either. Nor did subgroup analyses based on several prognostic variables (sex, pain duration, age and level of education) show statistically significant effects of interaction. 


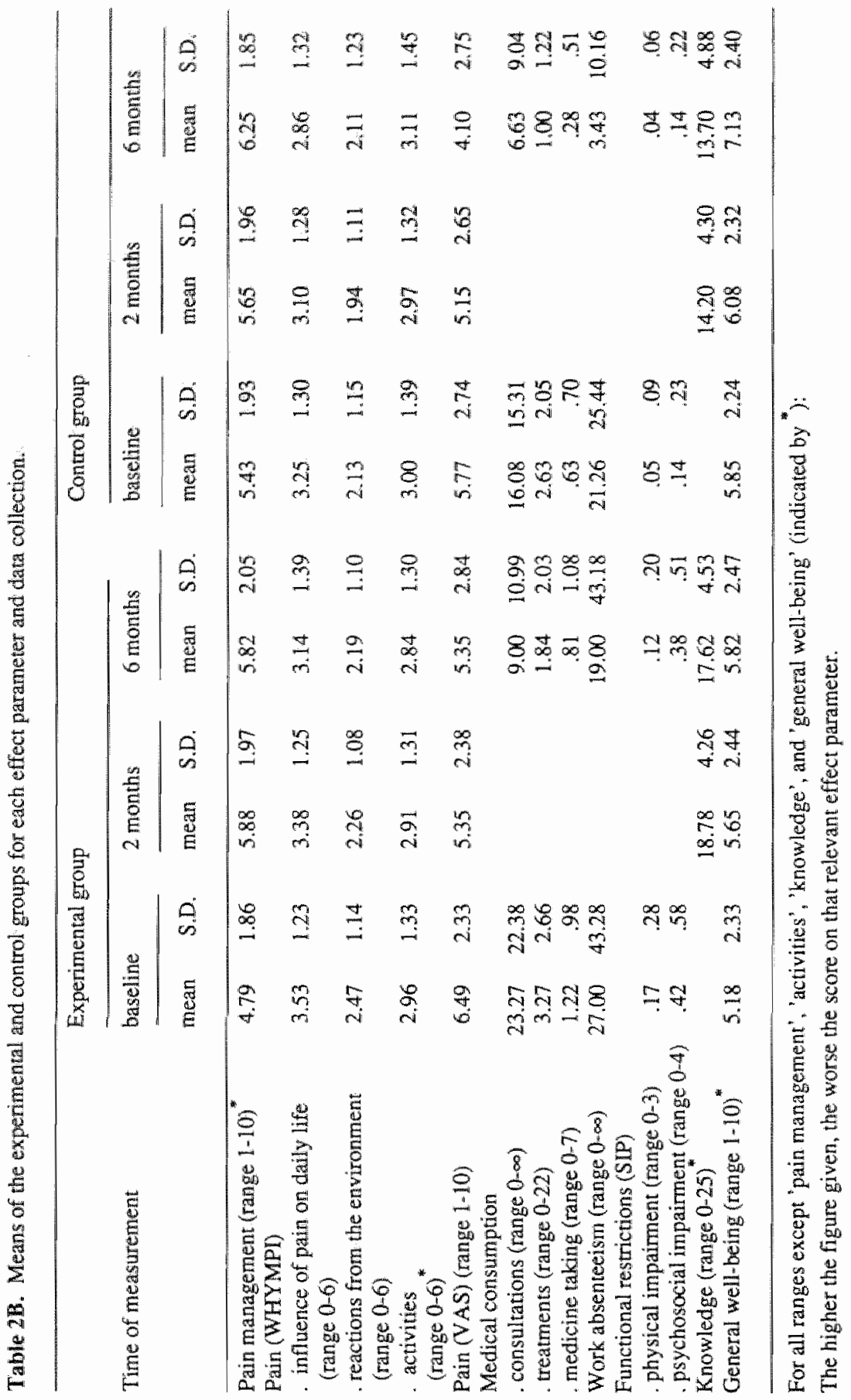


Summarizing the results it can be said for all effect parameters that:

1. Both the experimental group and the waiting list control group showed progress with time (significant effects of time). However, the experimental group did not show significantly more progress (effects of interaction not significant).

2. Although patients were randomly assigned to treatment groups, there were substantial differences in some prognostic variables (e.g. sex).

3. After adjustment for these differences there was still no difference in effect between the group receiving back school treatment and the waiting list control group.

\section{$\overline{\text { Conclusion }}$}

The present study failed to reject the null hypothesis stating that there is no difference in effect between a group receiving back school treatment and a waiting list control group. Besides the apparent inefficacy of the Maastricht Back School, some problems concerning the validity of the study need to be discussed.

1. The number of patients in the study was relatively small (77) and therefore only relatively large effects could be detected (lack of power of the study) (8).

2. Internationally acknowledged reliable and vallid effect parameters with regard to (low back) pain are scarce. Moreover, the available reliable and valid effect parameters might be insensitive to changes with time. For the Sickness Impact Profile (SIP), for example, interim surveys have shown satisfying results regarding its reliability and validity (1). On the other hand, the SIP may have been insensitive to changes with time (2).

3. The differences at baseline may be due to data collection after randomization instead of before. Filling out questionnaires knowing whether one can start with the back school might bias one's answers.

4. It might be argued that the differences in baseline scores were responsible for the non-existence of the expected significant effects of interaction. We do not think, however, that this is the case. More serious patients, who seem to be more prevalent in the experimental group, might have been expected to profit more from the treatment than the less serious patients in the control group. That is to say that the differences at baseline might in this case be expected to enhance the probability of finding significant effects of interaction.

5. Back pain complaints often fluctuate with time. Patients who sign up for a back school probably have serious complaints at that time and thus score extremely high, so that scores two and six months after randomization tend to be lower, due to fluctuations which are intrinsic to the natural history of their back pain. This implies that it will be difficult to show effects of the Maastricht Back School which are small compared to these fluctuations with time. On the other hand it can be argued that such small effects lack clinical relevance anyhow. 
6. A waiting list control group is not entirely comparable to a control group receiving a different or placebo intervention. In a waiting list control group, the knowledge that one will enter the desired back school treatment within half a year might allreadly have some therapeutic effect. Another possibility is that patients on a waiting list may seek some altemative treatment while waiting, or already start behaving in accordance with the ideas of the back school.

Although bias cannot be excluded from our study results, it does not seem very likely that the Maastricht Back School is an effective method of managing low back pain. Furthermore, due to the required multidimensional approach of pain in the Maastricht Back School, the results of this study further reduce the likelihood of any back school in its present set-up being effective. The limited evidence availabie from other randomized trials indicates at most borderline effects for other back schools (4.7). Very large trials with perfect methodology, avoiding the shortcomings of our own and other studies, might yet show some beneficial effects, although we do not think such trials deserve high priority.

\section{References}

1 Bergner, M., Robbit, R.A., Carter, W.B. \& Gilson, B.S.: The Sickness Impact Profile. Medical care 19: 787-805, 1981.

2 Deyo, R.A.: Measuring the Functional Status of Patients with Low Back Pain. Arch Phys Med Rehab 69: 1044-1053, 1988.

3 Frymoyer, I.W.: Back pain and sciatica. N Engl J Med 318: 291-300, 1988.

4 Keijsers, J.F.E.M., Steenbakkers, W.H.L., Gerards, F.M. \& Meertens, R.M.: The efficacy of the back school. An analysis of the literature. Arthritis Care and Research 3 : $210-215,1990$.

5 Kerns, R.D., Turk, D.C. \& Rudy, T.E.: The West Haven-Y̌ale Multidimensional Pain Inventory (WHYMPI). Pain 23: 345-35.6, 1985.

6 Linton, S.J.: Chronic pain: The case for prevention. Beh Res Ther 25: 313-317, 1987.

7 Linton, S.J. \& Kamwendo K.: Low Back Schools, A critical review. Physical Therapy 9: 1375-1383, 1987.

8 Pocock, S.J.: Clinical Trials, a Practical Approach. Chichester, 1983.

9 Tabachnick, B.G. \& Fidell, L.S.: Using Multiwariate Statistics. New York, 1989.

10 Twycross, R.G.: The assesment of pain in advanced cancer. J Med ethics 4: 112-116, 1978.

11 Zachrisson Forssell, M: The Back School. Spine 1: 104-106, 1981. 


\section{The impact of back school research on health care practice}

\section{A randomized survey among general practitioners and physiotherapists*}

Jolanda F.E.M. Keijsers, Lex M. Bouter, Ree M. Meertens, Alphons G.H. Kessels \& Paul G. Knipschild

* Submitted for publication

\section{ABSTRACT}

Back schools offer an education and skills program in a group setting and are primarily directed towards pain management. Randomized clinical trials including one done by our research group do not show back schools to be very effective. These research findings were summarized in a short overview. In order to determine the impact of this overview on health care practice, we conducted a randomized survey $(\mathrm{n}=170)$ among general practitioners and physiotherapists. The main question was to what extent they would change their belief in the efficacy of the back school when confronted with the empirical evidence. After stratification for prior belief and profession, the participants were randomly divided into two groups: one was shown the short overview of the empiricall evidence $(\mathrm{N}=82)$ while the other was not $(\mathrm{N}=88)$. Subsequently, they had to state their belief in the efficacy of the back school again. In the experimental group $52 \%$ reported a decreased belief, compared to $22 \%$ in the control group. The actual median likelihood ratio for the experimental group was 0.65 while for the controll group this was 1.00 . It can be concluded that the impact of the short overview consisted of a change in belief in the expected direction, although somewhat smaller than was expected. Future studies should further elucidate the determinants of the impact of empirical evidence on health care practice. 


\section{Introduction}

All too often, researchers in the field of health education seem to assume that it is enough to carry out well designed studies into the efficacy of educational programs, if one wishes to improwe actual health care practice. In fact, results of health education research are quite often not, or inadequately put into practice. Researchers should therefore conduct additionall studies in order to find out whether people working in the field of health care and health education act in accordance with the results of (scientific) research. In this article an example of such research, about the impact of back school research on health care practice, is described.

Back schools offer an education and skills program in a group setting, and are primarily directed towards pain management. Existing studies into the efficacy of back school treatment do not support the idea that back school treatment is very effective for patients with non-specific back pain (Keijsers et al, 1991). It can, however, be argued that in these back schools back pain is not, as it should be, approached in a multidimensional way: in addition to physical factors, psychosocial factors are also involved in both the etiology and progriosis of low back pain (Nachemson, 1979; Turk \& Flor, 1984). Therefore, the Maastricht back school was designed to be a combination of all those elements which we felt ought to be included in a back school information and training program (Keijsers et al., 1990a). However, a randomized clinical trial with our Maastricht back school showed no surplus value compared to a waiting list control group (Keijsers et al., 1990b).

The main results from both the existing literature and our own study conceming the efficacy of back school treatment were summarized in a short overview. This overwiew of research findings was based on two articles who at that moment were submitted for publication in an international joumal (Chapters 2 and 5). In order to estimate its impact on health care practice we conducted a randomized survey among general practitioners and physiotherapists who are familiar with back school treatment. The main research question was to what extent they would change their belief in the efficacy of the back school when confronted with the empirical evidence. In addition to this, the influence of four independent variables was studied. These variables were 1)initial (prior) belief, 2)profession, 3)reliance on results of scientific back school research, and 4)involvement in the planning and execution of back school treatment. 


\section{Methods}

The Netherlands Institute of Primary Health Care (NIVEL) registers all practitioners in the Netherlands working in primary health care. This Institute provided us with a random sample of 200 physiotherapists (PTs) and 200 general practitioners (GPs). These were invited by post to state their belief in the efficacy of back school treatment by indicating their belief in the hypothesis " back school treatment is effective for patients suffering from non-specific back pain". They had to do this on a ten-square visual analogue scale ranging from $5 \%$ to $95 \%$, with the anchor words "back school treatment is absolutely not effective" and "back school treatment is very effective". Those who did not respond within three weeks receiwed a reminder. The respondents were stratified according to profession (PT, GP) and prior belief (cut-off points $50 \%$ and $70 \%$ ), and within these six strata they were randomly divided into an experimental and a control group. The experimental group received our overview. All responders were then once again asked to state their belief in the efficacy of back school treatment. Our hypothesis was that the average posterior belief in the experimental group would be lower than the prior belief. Of course we expected the majority of the control group to state a posterior belief equal to their prior belief. The control group, who had not receiwed the overview, was promised they would get it as soon as we received their posterior belief in the hypothesis. Those who did not respond within three weeks received a reminder. GPs and PT's who at the first data collection stated not to be familiar with back school treatment, and those who did not state their belief in the efficacy of back school treatment twice, were excluded from the analysis.

\section{Data analysis}

In order to detect a change in belief concerning the efficacy of back school treatment, the prior belief $(\mathrm{PO})$ of subjects in the experimental and control groups were compared to the posterior belief (P1). To determine the influence of the four independent variables (prior belief, profession, reliance on scientific back school research, and involvement in back school treatment), the data were analysed within levels of these independent variables (stratified analyses). In addition, the impact of the overwiew was expressed quantitatively as a likelihood ratio (LR), which was calculated by dividing the odds of belief after reading the overview (or not) by that before reading it. For example, if the belief changes from $60 \%$ to $35 \%$, the corresponding likelihood ratio is equal to $(0.35 / 0.65) /(0.60 / 0.40)=0.36$. A LR of one indicates no impact. A LR between zero and one indicates that, compared to the prior belief, the posterior belief is lower; a LR higher than one indicates a posterior belief higher than the prior belief (Knipschild, 1989; Knipschild \& Leffers, 1990). 


\section{Results}

The rarudom sample of $400 \mathrm{GPS}$ and PTs were invited to state their belief in the hypothesis that the back school is effective for patients suffering from nonspecific back pain. At the first data collection 197 of the 400 subjects did not respond $(N=117)$, stated to be unfamiliar with back school treatment $(N=71)$ or did not state their prior bellief in the efficacy of the back school despite being familiar with it ( $\mathrm{N}=9$ ). Thus, 203 subjects were randomly assigned to an experimental $(\mathrm{N}=103)$ and a control group $(\mathrm{N}=100)$. 21 subjects in the experimental group and 12 in the control group did not state their posterior belief. Ultimately, 170 randomized subjects stated their belief in the efficacy of back school treatment twice. The mean time between stating the prior and posterior belief was about ten weeks.

Figure 1 shows the distribution of the prior by the posterior belief for the experimental and control groups. Each dot represents a single respondent. As can be seen, most dots for the experimental group are below the diagonal ( $L R=1)$, indicating on average a decreased belief in the efficacy of back school treatment.

The figure shows, for example, that in both groups 43 subjects had a prior belief of $55 \%$ or $65 \%$. Of these 43 subjects in the experimental group, 17 subjects had a lower posterior belief, while 13 had a higher posterior than prior belief. In all, 13 subjects had a posterior belief equal to their prior belief. In the control group, 6 of the 43 subjects had a lower posterior belief, and 15 subjects a higher posterior than prior belief. For 22 subjects the posterior belief was equal to the prior belief.

The curved lines indicate the median ( $\mathrm{p} 50)$, and second ( $\mathrm{p} 25)$ and fourth quartile (p75) likelihood ratios. The dotted line in the figure for the experimental group indicates a likelihood ratio equal to one. For the experimental group the actual median LR was 0.65 , with the second quartile and fourth quartile 0.28 and 1.25 respectively. The median LR for the control group was 1.00 , with the second quartile 0.70 and the fourth quartile 1.50 .

Changes in belief were obtained for both groups by subtracting the prior belief from the posterior belief. The distribution of these changes in the experimental group (mean change $-10 \%$ ) was significantly different from that in the control group (mean change 1.6\%) (t-test; $\mathrm{p}<0.05$ ). The mean change in the control group points to an, on average, slightly increased belief. 


\section{EXPERIMENTAL GROUP}

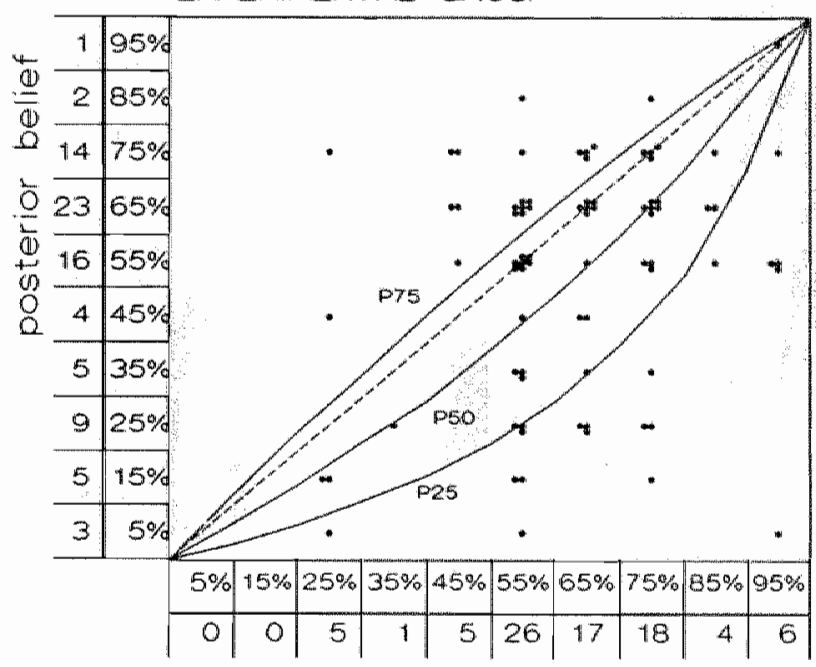

prior belief

\section{CONTROL GROUP}

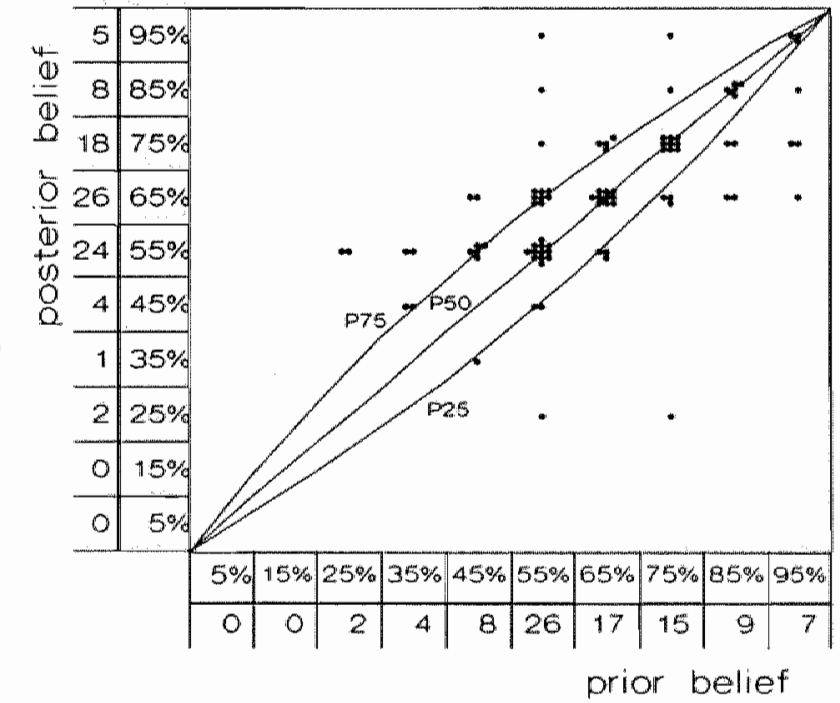

Figure 1. Distribution of the prior by the posterior belief in the efficacy of back school treatment for the experimental group $(\mathrm{N}=82)$ and control group $(\mathrm{N}=88)$. Curved lines indicate median (p50), second (p25) and fourth quartile ( $\mathrm{p} 75$ ) likelihood ratios. The dotted line in the figure for the experimental group represents a likelihood ratio of one. 


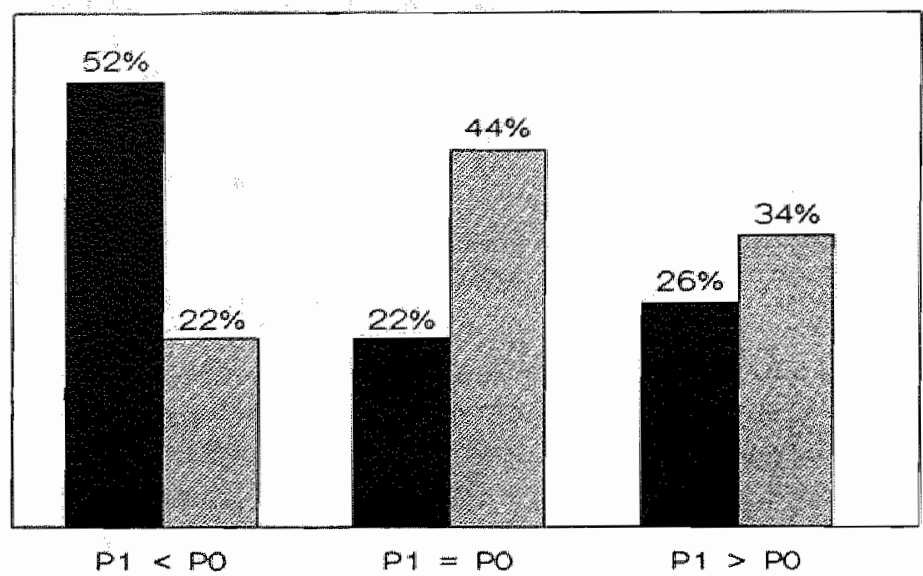

Figure 2. Percentages of subjects in the experimental $(N=82)$ and control groups $(N=88)$ with a posterior belief (P1) lower than, equal to or higher than the prior belief (P0).

Figure 2 shows the percentages of subjects in the experimental and control groups with a posterior belief (PI) lower than, equal to and higher than the prior belief (P0). More than half the subjects in the experimental group had a P1 lower than P0; in the control group almost half of the subjects had a P1 equal to P0.

For both groups, table 1 gives percentages of subjects with a posterior belief (P1) which was lower than their prior belief (PO), within levels of the independent variables. The differences between the percentages for both groups within each level are given as well. With respect to prior belief and reliance on results of scientific back school research, the stratification into these levels is mainly based on getting sufficient numbers of subjects within each level, as well as on interesting prior distinctions. The differences provide an indication of the impact of the overview after adjustment for the percentage of respondents that change their belief in the expected direction (P1 $<$ P0) without receiving the overview. Figure 2 shows that in the total population this difference is $30 \%$.

It turns out that large differences between the experimental and control group are most apparent for participants with a high prior belief $(75-95 \%)$ and for participants who strongly rely on results of scientific back school research. The effect of profession or personal involvement in back school treatment seems to be less important. 
Table 1. Percentages of subjects in the experimental and control groups who had a posterior belief ( $\mathrm{P} 1)$ lower than the prior belief $(\mathrm{PO})$ within lewels of fout independent variables.

\begin{tabular}{|c|c|c|c|c|c|}
\hline \multirow[b]{2}{*}{ Independent variables } & \multicolumn{2}{|c|}{ Experimental } & \multicolumn{2}{|c|}{ Contral } & \multirow[b]{2}{*}{ difference } \\
\hline & $\mathbf{N}$ & $\mathrm{Pl}<\mathrm{PO}$ & $\mathbb{N}$ & $\mathrm{Pl}<\mathrm{PO}$ & \\
\hline \multicolumn{6}{|l|}{$\mathrm{PO}$} \\
\hline $5-45 \%$ & 11 & $36 \%$ & 14 & $7 \%$ & $29 \%$ \\
\hline $55-65 \%$ & 43 & $40 \%$ & 43 & 140 & $26 \%$ \\
\hline $75-95 \%$ & 28 & $79 \%$ & 31 & $39 \%$ & 409 \\
\hline \multicolumn{6}{|l|}{ Profession } \\
\hline GP & 31 & $55 \%$ & 31 & $29 \%$ & $26 \%$ \\
\hline $\mathrm{PT}$ & 51 & $51 \%$ & 57 & $17 \%$ & $34 \%$ \\
\hline \multicolumn{6}{|l|}{ Reliance } \\
\hline $5-55 \%$ & 21 & $48 \%$ & 22 & $27 \%$ & $21 \%$ \\
\hline $65-75 \%$ & 33 & $51 \%$ & 40 & $25 \%$ & $26 \%$ \\
\hline $85-95 \%$ & 28 & $57 \%$ & 26 & $11 \%$ & $46 \%$ \\
\hline Involved & 11 & $64 \%$ & 11 & $36 \%$ & $28 \%$ \\
\hline not involved & 71 & $51 \%$ & 77 & $19 \%$ & $32 \%$ \\
\hline
\end{tabular}

\section{Discussion}

So far, research has not been able to show clear efficacy of the back school. In our randomized survey, the impact of this empirical evidence on health care practice was estimated. It was expected that GPs and PTs who were confronted with our short overview of research results, would show a substantial decrease in their belief in the efficacy of back school treatment. GPs and PTs in the control group did not receive the overview. Consequently, they were expected not to change their belief.

In the control group, $56 \%$ indicated a change in their belief (34\% higher posterior belief, $22 \%$ lower). Among the subjects with a relatively low prior bellief (lower or equal to $45 \%$ ), 13 of the 14 reported a posterior belief higher than the prior belief. On the other hand, of the 31 subjects with a relatively high prior bellief (belief higher or equal to $75 \%$ ) 12 reported a lower posterior than prior belief. Regression to the mean seems to be partly responsible for these effects. 
Surprisingly, of the experimental group $26 \%$ indicated an increased bellief in the efficacy of back school treatment despite exposure to the shor overview of mostly "negative" research results. Moreover, $22 \%$ reported no change in bellief. Only $52 \%$ had a PI lower than P0, which cannot be described as an overwhelming effect. The median likelihood ratio was 0.65 . A possible explanation might be sought in the compliance with the intervention among subjects in the experimental group, i,e, how thoroughly did they read the shor overview? A second possible explanation why the impact is lower than expected might be the amount of prior knowledge with regard to the efficacy of the back school. Subjects who have already read about research into back school treatment, might be less likely to change their mind after reading our overview. A third explanation for the disappointing effect might be that a change in belief cannot be expected immediately after reading the overview. A determination of the long term impact of the overview might reveal a larger decrease in belief. A fourth explanation of our findings could be that health care practitioners are more inclined to base their opinion about whether a treatment is effective on their experience in everyday practice. A study conducted by Boissel (1989) revealed that $44 \%$ of the GPs studied prescribe treatments on the basis of practical experience. Founding an opinion on practical experience is, however, not consistent with the finding that most of the GPS and PTs in our study reported that they relied moderately to heavily on results of scientific research. A fifth possible explanation could therefore be that the GPs and PTs lack methodical training, which is a necessary condition for understanding scientific articles and for acting in accordance with the findings presented. On the other hand, it could also be argued that researchers lack the skill to write intelligibly about scientific research and its implications for health care practice. In any case, increased cooperation between researchers and practitioners is advocated (Bohannon \& LeVeau, 1986; Kok \& Green, 1990).

In the present study, the control group was not exposed to a "placebo" overview, so it was not possible to make a distinction between the specific and non-specific effects of the overview. The effects might therefore be partly attributed, for example, to the fact that some subjects in the control group understood that they were expected not to change their belief, whereas the opposite could be the case for the experimental group.

It can be concluded that the impact of the short overview on GPs and PTs consisted of a change in belief in the expected direction, which was, however, not as large as we had expected. Further studies are needed into the determinants of the impact on health care practice of empirical evidence about the efficacy of an intervention, in order to maximalize the change in belief. 


\section{References}

Bohannon, R.W., LeVeau, B.F. (1986) Clinicians" use of research findings. A rewiew of literature with implications for physical therapists. Physical Therapy, 66, 45-50.

Boissel, J.P. (1989) Impact of Randomized Clinical Trials on Medical Practices: Controlled Clinical Trials, 10, 120S-134S.

Keijsers, J.F.E.M., Bouter, L.M., Stenbakkers, W.H.L., Meertens, R.M. (1991) Validity and comparability of studies on the effects of back schools. Accepted for publication in Physiotherapy Theory and Practice.

Keijsers, J.F.E.M., Steenbakkers, W.H.L., Gerards, F.M., Meertens, R.M. (1990a) The efficacy of the back school. An analysis of the literature. Arthritis Care and Research, 3 , 210-215.

Keijsers, J.F.E.M., Steenbakkers, W.H.L., Meertens, R.M., Bouter, L.M., Kok, G.J. (1990b) The efficacy of the back school. A randomized trial Arthritis Care and Research, 3, 204-209.

Knipschild, P. (1989) Changing belief in iridology after an experimental study. British Medical Joumal, 299, 491-2.

$\mathbb{K}$ nipschild, P.x Leffers, P. (1990) De informatiewaarde wan empirisch onder zoek. Tijdschrift voor Sociale Gezondheidszorg, 68 , no. 5 WEON, $31-32$.

Kok, G., Green, L.G. (1990) Research to support health promotion in practice: a plea for increased cooperation. Accepted for publication in Health Promotion Intemational.

Nachemson, A. (1979) A critical look at the treatment for low back pain. Scandinavian Journal of Rehabilitation Medicine, 11, 143-147.

Turk, D.C., Flor, H. (1984) Etiological theories and treatment for chronic back pain. II. Psychological models and interventions. Pain, 19, 209-233. 



\section{| Chapter 7}

\section{Discussion}

In this dissertation it is questioned whether back schools are effective for patients with non-specific low back pain. To answer this question all published studies on the efficacy of back schools were reviewed with regard to their validity (Chapter 4) and the content of the back schools (Chapter 2).

Various forms of the so-called back school have been developed. Some comprise modified versions of the Swedish back school, which is based on ergonomic advice. In these back schools low back pain is considered to be merely a physical complaint. Others schools briefly mention the psychosocial factors related to low back pain as well. The gate-control theory presented by Melzack and Wall (1982) led to a multidimensional perspective on pain: a view of pain consisting of psychosocial as well as physical components. On the basis of this multidimensional approach to pain, the Maastricht back school was develloped. Compared to other back schools, more emphasis is placed on the psychosocial factors associated with low back pain.

We investigated the efficacy of the Maastricht back school in two experiments (Chapter 3 and Chapter 5). To determine the influence of all research results so far on the opinion of health care practitioners about the efficacy of back school treatment, we subsequently conducted a randomized survey (Chapter 6).

Roughly, two conclusions can be drawn from the research presented in this dissertation. Firstly, the results of our experiments and those of other randomized trials did not enable us to demonstrate that back schools are effective for patients suffering from non-specific low back pain. Secondly, the influence of a review of all available randomized trials on the opinion of practitioners about the efficacy of back school treatment was in the expected direction (a decreased belief in the efficacy of back school treatment), but appeared to be some what smaller than was expected.

The discussion presented below investigates the extent to which these general conclusions might still be somewhat ambiguous. For this purpose we discuss the validity of the studies and the generalizability of the results. Furthermore, some possible explanations of our findings are presented , as well as some recommendations for the treatment of low back pain. 


\section{Validity of the studies}

The main problems concerning the walidity of all randomized trials investigating the efficacy of a back school are discussed in Chapters 4 and 5 . The validity of the randornized survey investigating the impact of empirical evidence on health care practice is discussed in Chapter 6 . In essence these discussions show that conducting a randomized trial offers no absolute guarantee for valid outcomes.

The randomization procedure, for example, as well as the number of persons in the study, are important factors in assessing the methodological quality (validity) of a study. If the randomization is performed properly it will in principle result in comparability of the experimental and control groups. It should be checked, however, to what extent the randomization has indeed been successful in achieving comparable groups. A small number of patients only allows the detection of large differences between the groups. On the other hand, when the sample size of a study is large, irrelevant differences may already show a high statistical significance.

The responsiveness of the effect parameters is another important issue. Effect parameters in trials should be sensitive in detecting clinically important changes over time. A lack of favourable effects of a back school might be due to the use of insensitive effect parameters. In other words, responsive effect parameters increase the power of a study, that is, the chance to detect an existing effect.

From the Chapters 4 and 5 it becomes clear that available randomized trials on the efficacy of back schools (including our own two studies) show a number of methodological flaws. Therefore, conclusions from these studies should be drawn with some caution. The biases in the several studies could have led to some degree of overestimation or underestimation of the efficacy of back schools.

All three randomized trials which we conducted involved a comparison between an experimental group and a waiting list control group. The question whether the results would have been similar if we had given the control group a placebo back school or a placebo overview (in the case of the impact study), cannot be answered. In health education research placebo interventions are usually difficult to realize and therefore hardly ever used. In the two trials on the efficacy of the Maastricht back school no substantial differences with the control groups were found, which makes the separation of the specific and non-specific effects an irrelevant problem. In the impact study, however, the difference with the control group could to some extent be due to non-specific effects of receiving the overview.

In our three studies the populations were not blinded. This means that all participants knew whether they were in the control group or in the experimental group. Furthermore, the persons assessing the effects of the interventions were the participants themselves. Especially for variables that involve some subjective judgement (e.g. pain management, belief in the empirical evidence), personal 
expectations of the participants regarding the compared interventions (presumably positive towards the back school or the rewiew article) might have led to some degree of overestimation of the effect in all three studies. However, it is also possible to argue in the opposite direction. An underestimation of the effects could be caused by participants who want to communicate that they are disappointed about the back school treatment or the review article. A tendency to please the investigator might have led to some overestimation as well. For the two trials among patients this is hardly a problem, because virtually no differences with the waiting list control groups were found. For the impact study, however, both the personal expectations and a tendency towards social desirability might have induced some (unknown) degree of overestimation of the impact of the review article. On the other hand, if the practitioners "expectations regarding the review article were negative, or if there was a tendency among practitioners to reject results of scientific research, the results might have been biased in the opposite direction.

In addition to this, a waiting list control group is not entirely comparable to a control group receiving no intervention or a different or placebo intervention. The patients and the practitioners in our waiting list control groups knew that they would receive the intervention after a certain period of time. This waiting may also have induced some degree of bias. In the randomized trials on the efficacy of the Maastricht back school, the patients in the waiting list control groups might have sought some other form of treatment for their pain while waiting or, on the contrary, abandoned other forms of treatment. Consequently, this could have biased the outcomes in both directions (over- and underestimation of the effect of back school treatment). The practitioners in the waiting list control group of the impact study might have been looked for information with regard to the efficacy of back schools while they were waiting. Depending upon the nature of the information received, such behaviour could have biased the results as well.

\section{Explanations for our findings}

Why were we not able to prove the Maastricht back school to be effeclive? The most straightforward answer would be that back schools have no effect at all. There are, however, some alternative answers. The idea that methodological limitations were responsible for the lack of effect was explored above. This section discusses whether the choice of patients or the operationalisation of the intervention might explain our "negative" results.

The efficacy of health eduaction, in this case the Maastricht back school, is generally assumed to depend mainly on the quality of the planning process (Green \& Lewis, 1986). In our study it was not possible to go through all the phases of this planning process in full detail. After defining the problem of low back pain we continued with the development of the Maastricht back school. The 
phases in between were based on a thorough study of the literature. No additional empirical research on the nature of low back pain and on the determinants of the behavioral risk factors was done. Such research could have revealed, for example, that health education in a group setting is less suitable for back pain patients. Future research should further elucidate the prognostic factors of low back pain and the determinants of the behavional risk factors involved.

With respect to the etiology and prognosis of low back pain it is recognized that it is not only physical factors but also psychosocial factors which are associated with low back pain (Melzack \& Wall, 1982). Hence, the Maastricht back school pays a great deal of attention to these factors. This school, however, turned out to be an ineffective method of managing low back pain. Should we therefore doubt the underlying theory? Since the psychosocial factors constituted only one component of our back school, it is impossible to formulate such a general judgement on the theory. Furthermore, if a factor is considered to be important in the etiology or prognosis of low back pain, this does not necessarily mean that a change in this factor will be accompanied by a change in low back pain. Another issue is that it might be difficult to actually change a certain factor, due to, for example, its complexity and its predominantly individual determinance. Because the Maastricht back schooll mainly offers an education program in a group setting, the psychosocial factors modulating pain are merely discussed in general. Superficiality and insufficient adjustment to the specific needs of the individual patient might therefore be possible explanations of the lack of efficacy.

It is possible that the general practitioners selecting and referring the patients in the second randomised trial of the efficacy of the Maastricht back school (Chapter 5) have been referring only those patients who kept complaining about their pain. The average pain duration in the study was 7.5 years, which is not at all in accordance with the inclusion criterium of low back pain for at least two months, with a maximum of three years. It is often assumed that the duration of the complaint has a prognostic influence on the effect of the intervention. As time passes by, the pain complaint could acquire a function in the patient's life: it might mean a liberation from threatening social contacts, chores and family responsibilities (Fordyce, 1978). With regard to back school treatment it has been postulated by some authors that patients whose pain problem is not yet chronic could benefit more (Lankhorst, 1983; Linton, 1987; Linton \& Kamwendo, 1987). The efficacy of the Maastricht back school for the patients in our study could therefore be less than in the group of patients we initially targeted.

Psychosocial characteristics of our patients might also be partly responsible for the disappointing results. However, the exact nature of the relevant characteristics, and whether these characteristics represent the causes or the results of the low back pain, is not known (Frymoyer, 1988). What their potential role is in modifying the outcome of back school treatment and spontaneous recovery is still controversial (Fisk et al., 1983; Love \& Peck, 1987. Hurri (1989b) found that, as compared to any clinical evaluation or objective measurement, work satisfaction 
was the best predictor for both the outcome of back school treatment and for spontaneous recovery. The results of a study performed by Julkunen et al. (1988) indicated that those patients who reacted favourably to the back school could be described as emotionally adjusted and controlled, and showing relatively good cognitive capacity. Patients showing spontaneous recovery in the control group were characterized by a more lively and less controlled way of expressing emotions and affects. Contrary to what is generally assumed (Sternbach ${ }^{\star} 1978$ ), significant correlations with depression or any other neurotic features and poor prognosis were not found in either of the two groups.

A common problem of health education, and thus of the back school, is that it requires active participation of the patients in the treatment process and typically teaches patients new skills. Medical treatment, such as medication, traction and manipulative therapy, tend to emphasize the skills of the physician and therefore place emphasis upon what Bandura (1977) has labelled the outcome expectancy: the expectancy that the treatment will be beneficial for the patient's problem and will satisfactorily resolve that problem. Minimal responsibility is placed on the patient. In contrast to this, health education focusses predominantly on what Bandura labels self-efficacy: the belief held by the patient that he or she can carry out the required behavior (e.g. relaxation) when the situation warrants it. Patients, however, have not been socialized to believe that they have control over severe physical problems themselves, and thus they do not readily adopt a self management perspective (Holroyd \& Creer, 1986)). Lack of motivation for even the smallest suggestion of self management is supposed to be a major obstacle in health education programs for patients with low back pain (Holroyd \& Creer, 1986). A high level of self-efficacy in pain management is connected with active participation of the patients. This active participation is only possible if patients understand the advice given and the exercises prescribed, and are able to carry out those exercises. In relation to this, characteristics of the participants and their immediate (social) environment (e.g. level of education and social support) might partly explain our results. However, we have no reason to assume that the patients in our studies generally lacked motivation or were unable to execute the prescribed exercises.

Despite the methodological limitations of back school research and the possible other explanations for the inefficacy of the Maastricht back school, we still conclude that back schools do not offer an effective treatment for low back pain patients.

The results of the randomised survey we conducted in order to determine the impact of the empirical evidence about the lack of efficacy of back school treatment on the opinion of physiotherapists and general practitioners were somewhat disappointing, although they showed a shift in the expected direction (Chapter 6). An explanation for this could be that health care practitioners are inclined to base their opinion about whether a treatment is effective on their personal experience in everyday practice rather than on results from scientific 
research. Another explanation could be that the practitioners lack methodical training, which is a necessary condition for understanding the quality of the research described in the overview. As an altemative explanation, it might be argued that we lack the skill to write clearly about scientific research and its implications for health care practice. Future research should focus on the reasons why practitioners change or do not change their opinion in the face of empirical evidence.

\section{Generalization of the results}

In Chapter 4 all available randomized trials on the efficacy of back schools in a group setting are reviewed. In the literature some additional randomized trials are available, which have assessed the efficacy of back school related programs in pain clinics or industry: Examples of the latter are the randomized trials reported on by Härrkäpaä et al. (1989) and Lindström et al. (1990). Both studies assessed the efficacy of a program for blue collar workers with low back pain, which included as one of its components the Swedish back school principles. The results from these studies show that, compared to the control groups, the treatment groups made significantly more progress on most effect parameters. Furthermore, some randomized trials have dealt with cognitive behavioral programs in pain clinics or rehabilitation centers. These programs provide a thorough and intensive training of cognitive behavioral techniques (Turk et al, 1983; Fordyce, 1976). There is some evidence for the efficacy of these programs in patients with chronic low back pain (Linton 1986; Linssen, 1990; Pearce, 1983; Vlaeyen, 1991). Thus, with regard to judgements about the efficacy of back schools, a clear distinction must be made between back schools and alternative management programs for low back pain patients. In addition, the setting (clinical or industrial) in which the efficacy of some program is determined is also important.

When making generalizations the inclusion and exclusion criteria for patients in the various studies is an important issue as well. Six of the nine available trials of the efficacy of back school treatment included chronic low back pain patients. In three of these six studies the authors concluded that the back school is effective. In the remaining three studies the efficacy of back school treatment could not be demonstrated. Three studies aimed at acute or subacute low back pain patients. Only one of these studies provided evidence favouring back school treatment. If back school treatment is effective, it is unclear for which subgroup of low back pain patients (in terms of duration of the complaint). Three studies recruited their patients in an industrial setting. Two of them reported positive effects for the back school. This seems to suggest that back schools in an industrial setting might have some positive effects. However, a comparison of the 
numbers of "positive' and 'negative" studies published might lead to biased conclusions as a result of publication bias, the tendency of joumals to favour "positive" studies.

Because the selection criteria in the trials are so various, it is difficult to compare and generalize the results. This means that even when identical back school programs are offered, differences in characteristics of the patients included might be partly responsible for the differences in effects found.

\section{Recommendations for the treatment of patients with low back pain}

Back schools are still being organised on a large scale (Knibbe et al., 1991). They appear to remain an attractive and relatively cheap treatment for patients with low back pain. Even the Maastricht back school is continued by health care practitioners, most probably because of its warm reception by back pain patients. The process evaluation revealled that the patients were very positive about all aspects of our back school program.

The fact that back schools are still being organised in health care forms a striking contrast with the fact that research has so far not been able to demonstrate their efficacy convincingly. It is not clear which back school, if any, is effective for which subgroup of low back pain patients. There is, nevertheless, some evidence for the efficacy of back schools in industrial settings. In any case, referring patients with low back pain to some back school in a health care setting does not seem advisable from a scientific point of view.

The problem is that most other treatment alternatives for low back pain do not seem to be very effective either (Flor \& Turk, 1984; Frymoyer, 1988; Spitzer et al., 1987; Turk \& Flor 1984; Waddell, 1987). Treatment modalities frequently advised are analgesics, (bed) rest, physiotherapy and manipulative therapy (Waddell, 1987). In an article reporting on the work of a prestigious Canadian task force by Spitzer et al. (1987), the scientific literature on treatment for spinal disorders is thoroughly reviewed, with the purpose of formulating recommendations for practitioners. Little scientific evidence was found to support current methods of treating low back pain. Their study demonstrated that in current practice the large majority of treatment modalities are used on the basis of the opinion of a practitioner regarding its efficacy, but without scientific proof. Nevertheless, a guideline for the management of patients with a spinal disorder is presented by these authors. In this management model three chronologic points in the development of back pain are stressed: 4 weeks, 7 weeks and 3 months. These moments in time are based on knowledge of the natural history of back pain and serve in the early detection of patients with a tendency toward chronic pain. It is pointed out that unless clinical signs suggest a specific pathology, all laboratory 
evaluations are generally useless over the first four weeks. Instead, the importance of the physical examination and history of the onset is emphasized. Bed rest should only be prescribed for two days at a time, to a maximum of 4 days. Functional rehabilitation ought to be the goal of the treatment. Between 4 and 7 weeks a complete reevaluation of the problem should be focussed on. Reassurance, education and preparing the patient for the physiological consequences of pain and inactivity are important in this phase of the complaint. If the patient's complaint has not disappeared after 6 weeks and a specific diagnosis can still not be made, a specialist should be consulted. After 3 months, a multidisciplinary consultation is strongly advised.

As long as no particular treatment has proved to have a real surplus value, the therapeutic decision about the type of treatment the patient is to be referred to might just as well be taken upon motives other than the specific content of a treatment. Such motives could be, for example, the cost of a treatment for the patient and for society, or the acceptance of a treatment by patients. Furthermore, the accessibility of the treatment could be such a motive.

If we may anticipate on the results of future research into the nature of low back pain and the determinants of the behavioral risk factors, it is quite possible that a new treatment will be developed that does have a surplus value resulting from its specific content. It does not seem very likely, however, that one treatment will be discovered which will be beneficial to all back pain patients. Future research will almost certainly reveal that the broad category of non-specific low back pain in fact consists of a number of different subgroups, which are homogeneous with regard to the effects of therapeutic interventions. For the time being, further research on the nature of low back pain and its crucial prognostic factors seem to deserve high priority.

\section{References}

Bandura, A. (1977). Self efficacy: Toward an unifying theory of behavioral change. Psychological Review, 84, 191-215.

Bergquist-Ullmann, M. \& Larsson, U. (1977). Acute low back pain in industry. Acta Orthopaedica Scandinavica, (suppl. 170), 1-117.

Fisk, J,R., Dimonte, P. McKay Courington S. (1983). Back schools, past, present and future. Clinical Orhopaedics and Related Research, $179,18-23$.

Flor, H. \& Turk, D.C. (1984). Etiological theories and treatment of chronic back pain. I. Sonatic models and treatment. Pain, 19, 105-121.

Fordyce, W.E. (1976). Behaviorial methods for chronic pain and illness. Saimt Louis: The C.V. Mosby Company.

Fordyce, W.E. (1978). Learning processes in pain. In: Sternbach R.A., red. The psychology of pain. New York: Rawen Press.

Frymoyer, J.W. (1988). Back pain and sciatica. The New England Journal of Medicine, 318 , $291 \cdot 300$ 
Green, L.W. \& Lewis, F.M. (1986). Measurement and Evaluarion in Health Education and Health Promotion. Pillo Alto: Maytield.

Harkâpaia, K., Jarvikoski, A., Mellin, G., Hurr, H. (1989). A controlled study on the outcome of inpatient and outpatient treatment of low back pain. Soun IRelwa Med, 21 . $81-89$.

Holroyd, K.A \& Creer, T.L. (1986). Self management of chronic disease. Handbook of clinical interventions and research. Chapter: 1,2,14. Academic Press ${ }_{\mathrm{q}}$ Inc.

Hurri, H. (1989). The Swedish back school in chronic low back pain. Part I. Benefirs. Scan J Rehab Med, $21,33-40$.

Hurri, H. (1989b). The Swedish back school in chronic low back pain. Part II. Factors predicting the outcome. Scand J Rehab Med, 21, 41-44.

Julkunen, J., Hurri, H., Kunkainen, J. (1988). Psychological factors in the treatment of chronic low back pain. Follow-up study of a back school intervention. Psychother Psychosom, 50, 173-181.

Kribbe, J.J, Knibbe N.E., Oostendorp, R.A.B., Elvers, J.W.H. (1991). Inventarisatie vain rugscholen in Nederland. SWSF Amersfoort, publicatie in voorbereiding.

Lindstrờm, I, Ohlund, C., Eek, C., Walin, L., Peterson, L-E., Nachemson, A. (1990). An activation program with work return for LBP patients. Results of a tandomized study in industry. Proceedings 3 rd Int Physiotherapy Congress Hong Kong. Sydney: Link Printing Pty Litd.

Linssen, C. (1990). Pinbeheersing, een cursus voor mensen met rugpijn. [Painmanagement, a pain control course for people with back pain]. Dissertation University of Leiden, The Netherlands.

Linton, S.J. (1986). Behavioral remediation of chronic pain: a status report. Pain, 24, 125-141.

Linton, S.J. (1987). Chironic pain: The case for prevention. Beh Res Ther, 25, 313-317.

Linton, S.J. \& Kanwendo K. (1987). Low back schools, A critical review. Physical Therapy, $67,1375-1383$.

Love, A.W. \& Peck, C.L. (1987). The MMPI and psychological factors in chronic low back pain: a teview. Pain, 28, 1-12.

Melzack, R. \& Wall, P.D. (1982). The challenge of pain. New York Basic Books.

Pearce, S. (1983). A review of cognitive behavioral methods for the treatment of chronic pain. Journal of Psychosomatic Research, 27, 209-233.

Spitzer, W.O., LeBlanc F.E., Dupuis, M. (1987). Scientific approach to the assessment and management of activity-related spinal disorders. Spine, 7, (Suppl. 1), 1-59.

Stankowic, R. \& Johnell, O. (1990). Conservative treatment of acute low back pain, A prospective randomized trial: McKenzie method of treatment versus patienc education in "Mini Back School". Spine, 15, 120-123.

Sternbach, R.A. (1978). Clinical aspects of pain. In: Sterrbach, R.A., ed. The psychology of pain. New York: Raven Press.

Turk, D.C. \& Flor, H. (1984). Etiological theories and treatment of chronic back pain. II. Psychological models and interventions. Pain, 19, 209-233.

Turk, D.C., Meichenbaum, D.H., Genest, M. (1983). Pain and behavioral medicine:A cognitiwe-behavioral perspective. New York: Guilford Press.

Waddell, O. (1987). A new clinical model for the treatment of low-back pain. Spine, 12 , 632-644.

Vlaeyen, I.W.S. (1991). Chronic low back pain, assessment and treatment from a behavioral rehabilitation perspective. Dissertation Uniwersity of Limburg, The Netherlands. 



\section{Summary}

Low back pain is a frequent health problem in Western countries. It is estimated that $80 \%$ of all people experience back pain during their active life. The majority of patients with acute low back pain recover within a few weeks. In about $90 \%$ of cases the complaints disappear within a few months. However, recurrences are frequent $(40-60 \%)$. The complaints are mostly non-specific, which means that no clear underlying pathology can be established. One popular treatment of patients with non-specific low back pain is an education and skills program called back school.

The central question of this dissertation is whether back schools are effective. Furthermore, it deals with the impact of the available empirical evidence about the efficacy of back schools on (para)medical health care practice.

In Chapter 1 the subject of the dissertation as well as the contents of the various chapters are briefly introduced.

Chapter 2 reviews the contents of various back schools. Considerable differences are found. Consequently, the word back school does not refer to one specific education and skills program. Furthermore, in most back schools low back pain is not; as it should be, approached in a multidemensional way. "The Maastricht back school, which we have developed, is presented. It is pointed out that in this back school it is not only the physical factors which are taken into account, but also the psychosocial factors which are involved in both the etiology and prognosis of low back pain.

At the University Hospital of Maastricht the Maastricht back school was initially tested in a randomised trial. The critera for acceptance into the study were low back pain for at least six months and no suspicion of underlying pathology (e.g. malignancy, herniated disc). Exclusion criteria were a certain degree of dogmatism and psychopathology. After checking the eligibility, 40 patients were prestratified by the duration of the complaints and randomly assigned to an experimental and a control group. The patients in the control group were promised back school treatment at the end of the study. Important measures of effect were pain , degree of depressiveness, activity level and coping strategy. Measurements were taken before, immediately after, and eight weeks after the intervention. The results of this pilot study are presented in Chapter 3. It was found that, with the exception of somatic fixation and the seeking of social support, the Back School program could not be proved to be effective for patients with chronic low back pain. 
The validity and comparability of all available randomised trials on the efficacy of back schools $(\mathrm{n}=8)$ are discussed in Chapter 4 . The studies were assessed on the following criteria: duration and content of the back school, selection criteria and number of patients involved, interventions and measures of effect used. With regard to the internal validity of the studies a number of gaps were found. The numbers of patients involved in the studies were relatively low, no placebo-attention group was used and the principal target of the back schools was not evaluated directly. Due to these gaps a strong and valid judgement on the efficacy of the back schools studied in the various trials cannot be formulated. In addition to this, the comparability of the studies is rather low. This is due to differences in patient- and intervention-related factors which have an important prognostic influence on the effect of back school treatment. Taken together the available studies do not suggest that back schools are impressively effective.

Chapter 5 presents the results of another randomised trial $(n=77)$ which we conducted on the efficacy of the Maastricht back school, comparing a back school group with a waiting list control group. This study was carried out in a primary health care setting. The inclusion criteria for the study required the presence of low back pain for at least two months, with a maximum of three years and no suspicion of underlying pathology. Patients who were unable to participate in a physical exercise program and a relaxation training were excluded. The most important measures of effect were pain, pain management, medical consumption and absenteeism from work. Measures were taken at baseline, and two and six months after randomisation. The results suggest inefficacy of the Maastricht back school for all measures of effect. Randomised trials on the efficacy of back schools in a health care setting indicated at most borderline effects for other back schools. Very large trials with perfect methodology, avoiding the shortcomings of our own and other studies, might yet show some beneficial effects. We do not feel, however, that such trials deserve high priority.

Chapter 6 presents the results of a randomised survey $(n=170)$ among general practitioners and physiotherapists into the impact of back school research on health care practice. For this purpose the findings of our own and other randomised trials on the efficacy of back schools were summarized in a short overview. The main question was to what extent they would change their belief in the efficacy of back school treatment when confronted with the empirical evidence. After stratification by prior belief and profession, the participants were randomly divided into an experimental and a control group. The experimental group $(n=82)$ was shown the overview of the empirical evidence, while the control group $(n=88)$ was promised the overview at the end of the study. Subsequently, they had to state their belief in the efficacy of the back school again. In the experimental group $52 \%$ reported a decreased belief, compared to $22 \%$ in the control group. The impact of the short overview thus consisted of a change in belief in the expected direction, although somewhat smaller than had been expected. Some possible explanations for the findings are discussed. 
Chapter 7 provides a discussion of the material covered by this dissertation. In the first part attention is drawn to the methodological limitations of the studies. It is pointed out that conducting a randomised trial offers no absolute guarantee for valid outcomes. In trials the use of measures of effect which do not seem to be responsive to changes in time is an important validity problem. Furthemore, because of the absence of placebo intervention in most studies, blinding of the study population and the measurement of outcomes were not possible. It is emphasized that, because of the methodological flaws in the randomised trials, conclusions should be drawn with some caution. In the second part some plausible explanations of our research findings are given. It is argued, for example, that the development of the Maastricht back school might be based on an incomplete idea about pain behavior and its determinants. A reasonable explanation for the somewhat disappointing impact of the overview on health care practitioners might be that health care pratitioners are more inclined to base their opinion about whether a treatment is effective on their personal experience in everyday practice. The third part of the chapter discusses the extent to which the results can be generalized. When making generalizations it is important to distinguish alternative pain management programs from back schools. The setting (e.g. industry or health care) in which the efficacy of a back school is assessed has important implications for the generalizations as well. In addition, the question which patients are included in the various studies is an important issue. Finally, this chapter presents some recommendations for the treatment of low back pain. Despite the largely 'negative' research results, back schools are still being organised on a large scale. From a scientific point of view, however, referring low back pain patients to a back school in a health care setting seems less than advisable. 



\section{Samenvatting}

Lage rugpijn (LRP) is een veel gehoorde klacht. Van de bevolking heeft $80 \%$ ooit last van lage rugklachten. Over het algemeen duurt LRP kort $(90 \%$ minder dan twee maanden), maar recidiveert vaak (40-60\%). De klachten zijn veelal niet-specifiek, hetgeen betekent dat er geen sprake is van een duidelijke onderliggende pathologie die de oorzaak van de klacht vormt. Als een van de behandelingsmogelijkheden voor lage rugklachten kennen we de laatste jaren de uit Zweden afkomstige rugschool. Rugscholen zijn cursussen die veelal in groepsverband worden gegeven en bestaan uit een aantal lessen. Het principe waarop rugscholen gebaseerd zijn, is dat door middel van voorlichting en training, kennis en vaardigheden vergroot worden. Centraal staat de beheersing van het rugpijnprobleem door de patiënt zelf.

De centrale vraag in dit proefschrift is of rugscholen effectief zijn. Tevens handelt het proefschrift over de invloed van uitkomsten van wetenschappelijk onderzoek naar de effectiviteit van rugscholen op de mening van (para)medici.

In Hoofdstuk 1 wordt het onderwerp van de dissertatie kort geîntroduceerd en worden de verschillende hoofdstukken ingeleid.

In Hoofdstuk 2 wordt een overzicht gegeven van de inhoud van gerapporteerde en geèvalueerde rugscholen in groepsverband. Deze blijken nogal verschillend te zijn. De term tugschool verwijst derhalve niet naar een vast omlijnd cursusprogramma. Verder blijkt dat vergeleken met andere rugscholen, in de door ons ontwikkelde Maastrichtse rugschool aandacht wordt besteed aan zowel de lichamelijke als ook de psychosociale aspecten van pijn (multidimensionele benadering).

In het Academisch Ziekenhuis Maastricht werd de effectiviteit van de Maastrichtse rugschool in een gerandomiseerd experiment onderzocht. De selectie criteria voor deelname aan het onderzoek waren niet-specifieke LRP voor de duur van minstens zes maanden en afwezigheid wan dogmatisme en psychopathologie. Op basis van de duur van de klacht werden 40 patiënten gestratificeerd en vervolgens random verdeeld over een experimentele en controle groep. De patiënten in de controle groep konden het rugschoolprogramma na afloop van het onderzoek doorlopen. Belangrijke effectmaten in deze pilot studie waren pijn, mate van depressieve gevoelens, activiteitenniveau en wijze wan coping. Metingen werden voor, na, en acht weken na de interventie verricht.. De resultaten van dit gerandomiseerd experiment $(n=30)$ worden in Hoofdstuk 3 gepresenteerd. Met uitzondering van somatische fixatie (onderdeel van de effectmaat pijn) en het 
zoeken van sociale steun (onderdeel van de effectmaat copingwijze), bleken er geen statistisch significante verschillen te zijn tussen de experimentele groep en de controle groep.

In Hoofdstuk 4 wordt onderzoek naar de effectiviteit van rugscholen beoordeeld op de interne validiteit en de onderlinge vergelijkbaarheid. Hiertoe worden alle in de literatuur beschreven studies besproken die gebruik maken van een at random aangewezen vergelijkingsgroep $(n=8)$. De onderzoeken worden op de volgende criteria beoordeeld: duur en inhoud van de rugschool, gehanteerde selectie criteria en grootte onderzoekspopulatie, interventies en effectmaten. Voor wat betreft de interne validiteit van de studies zijn de volgende lacunes geconstateerd. Er worden relatief weimig patiënten in de studies opgenomen, er wordt in de opzet van de studies geen gebnik gemaakt van een placebo-dandachtsgroep en een directe evaluatie van de doelstelling wan de rugscholen wordt niet uitgevoerd. Deze geconstateerde lacunes maken het vooralsnog onmogelijk tot een valide uitspraak te komen over de effectiviteit van de binnen de afzonderlijke studies onderzochte rugscholen. De onderlinge vergelijkbaarheid van de studies is gebrekkig. Dit vanwege verschillen in interventies en patienten die van crucial belang voor het effect van rugschoolbehandeling worden geacht. De resultaten van de studies kunnen niet eenduidig het veronderstelde positieve effect van rugscholen bevestigen.

In Hoofdstuk 5 worden de resultaten van een experiment gericht op de effectiviteit van de Maastrichtse rugschool in de eerste lijnsgezondheidszorg gepresenteerd. Inclusie criteria woor het onderzoek waren niet-specifieke LRP en een klachtduur van minimaal twee maanden en maximaal drie jaar. Patienten die niet in staat waren spierwersterkende oefeningen en ontspanningsoefeningen uit te voeren werden niet tot het onderzoek toegelaten. Belangrijke effectmaten in deze studie waren pijnbeheersing, pijn, medische consumptie en werkwerzuim. Metingen werden bij aanvang, en twee en zes maanden na de randomisatie verricht. De resultaten laten zien dat er geen statistisch significant verschil in effect is tussen de groep die de Maastrichtse nugschool volgde en de wachtlijst controle groep. Ook andere gerandomiseerde experimenten konden niet eenduidig het veronderstelde positieve effect van rugscholen bevestigen. Een goed opgezet experiment met een groot aantal patiënten kan misschien nog enig effect van rugscholen aantonen. Het is echter de vraag of een dergelijke studie een hoge prioriteit werdient.

De resultaten van een gerandomiseerd experiment $(n=170)$ gericht op de invloed van empirisch onderzoek op de mening van huisartsen en fysiotherapeulen worden in Hoofdstuk 6 gepresenteerd. Ten behoeve van dit onderzoek werd een samenvattend artikel over de effectiviteit van rugscholen geschreven. In dit artikel worden de resultaten van onderzoek naar de effectiviteit van de rugschool, inclusief onze eigen onderzoeksbevindingen "gepresenteerd. Gebaseerd op de wooraf mening over de effectiviteit van de rugschool en beroep (huisarts of fysiotherapeut) werden de deelnemers at random verdeeld over een experimente- 
le en controle groep. De experimentele groep kreeg het samenvattend artikel toegestuurd. De controle groep ontving alsnog het samenwattend artikel na de onderzoeksperiode. Vervolgens werd bij beide groepen nog een keer geïnformeerd naar de mening over de werkzaamheid van de rugschool. Het merendeel in de experimentele groep gelooft, vergeleken met de vooraf meting, bij de achteraf meting minder in de effectiviteit van de rugschool $(52 \%)$. Voor de controle groep is dit $22 \%$. De impact van de onderzoeksbevindingen op de mening van huisartsen en fysiotherapeuten is, althans op korte termijn, positief te noemen. Echter, niet in die mate zoals we verwacht hadden. Tot slot worden enkele mogelijke verklaringen voor de resultaten gepresenteerd.

Hoofdstuk 7 bevat een discussie van de bevindingen zoals gepresenteerd in het proefschrift. In het eerste gedeelte worden de voornaamste methodologische beperkingen van gerandomiseerde experimenten besproken. Benadrukt wordt dat het uirvoeren van een experiment geen garantie biedt voor valide uitkomsten. De gevoeligheid van meetinstrumenten om klinisch relevante veranderingen te detecteren is in dit verband een belangrijk punt. Omdat in de meeste studies geen placebo interventie is opgenomen waren blindering van de studie populatie en de. metingen niet mogelijk. Gezien de methodologische beperkingen van de experimenten dienen de conclusies met enige terughoudendheid te worden betracht. In het tweede gedeelte van dit hoofdstuk worden enkele mogelijke verklaringen voor de onderzoeksresultaten gegeven. Een mogelijke verklaring voor de ineffectiviteit van de Maastrichtse rugschool is bijvoorbeeld dat de interventie gebaseerd is op een onvolledig inzicht in de prognostische factoren de van invloed zijn op LRP. De tegenvallende impact van het samenwattend artikel op huisartsen en fysiotherapeuten is wellicht te wijten aan het feit dat de keuze voor een bepaalde behandeling vooral gebaseerd wordt op de eigen ervaring in de praktijk. De generaliseerbaarheid van de onderzoeksresultaten wordt in het derde gedeelte van het hoofdstuk aan de orde gesteld. In dit verband wordt gewezen op de diversiteit aan pijn management programma's. Ook de setting (bijwoorbeeld een bedrijf) waarin de effectiviteit van een rugschool wordt bepaald heeft consequenties voor de generaliseerbaarheid van de resultaten. Tot slot worden in dit hoofdstuk aanbevelingen gedaan voor de behandeling van lage rugklachten. Er wordt opgemerkt dat hoewel resultaten van wetenschappelijk onderzoek veelal negatief zijn, rugscholen nog steeds op grote schaal worden georganiseerd. 


\section{Dankwoord}

De basis van het onderzoek beschreven in dit proefschrift is gelegen in een ogenschijnijik onschuldig onderzoeksvoorstel dat ik schreef met Frans Gerards en Gerjo Kok. Ik had nooit gedacht dat enkele jaren later een proefschrift het resultaat zou zijn. En dat is maar goed ook!

Terugkijkend op de afgelopen jaren realiseer ik mij terdege dat velen bij het hier beschreven onderzoek een rol hebben gespeeld. Zo zou het onderzoek niet mogelijk zijn geweest zonder de medewerking van de diverse rugpijn patiënten, docenten, huisartsen en fysiotherapeuten. I dank hen allen.

De onderzoeksperiode kenmerkte zich door een hechte samenwerking tussen de vakgroepen Gezondheidswoorlichting en -opvoeding (GVO) en Epidemiologie/Gezondheidszorgonderzoek van de Rijksuniversiteit Limburg. Recht doend aan deze voor mij zeer leerzame samenwerking, wil ik een aantal personen bedanken.

Binmen de vakgroep GVO is dit in de eerste plaats Mieke Steenbakkers. Hoewel je niet tot het einde van de rit intensief betrokken kon blijven bij het onderzoeksproject, heb je terdege belangrijke fundamenten gelegd. Ree Meertens bedank ik voor haar begeleiding in met name de data-analyse. Frans Gerards voor zijn initiërende rol. Promotor Gerjo Kok voor zijn begeleiding veelal op afstand. Je werkwijze 'geen bericht, goed bericht' was even wennen maar bleek indicatief voor een prettige samenwerking.

De vakgroep Epidemiologie was met name in de persoon van Lex Bouter bij het onderzoek betrokken. Van hem heb ik heel veel geleerd: van het opzetten, uitvoeren en rapporteren van onderzoek tot en met het houden wan voordrachten. Tweede promotor Paul Knipschild leverde met zijn creatieve suggesties de basis voor de laatste fase van het onderzoek.

Alle collega's van de vakgroep GVO bedank ik voor de prettige en vriendschappelijke werksfeer. Collega, maatje, en vriendin Olga van Rijn bedank ik in 'net bijzonder. Je humor, spontaniteit, flexibiliteit en positieve instelling waren voor mij zeer waardevol. "Tot ziens bij bureau 'Keijsers \& van Rijn'!

Jan Klerkx bedank ik voor de accurate wijze warop hij mijn engelstalige artikelen becommentarieerde.

Naast woorden van dank gericht aan personen in mijn directe werkomgeving, wil ik al mijn vrienden daarbuiten laten weten dat zij een enorme steun voor mij zijn geweest in de voltooing van dit proefschrift.

Tot slot, maar zeker niet in de laatste plaats, wil ik mijn ouders bedanken voor het vertrouwen dat $z i j$ in mij gesteld hebben en voor hun levenslange begeleiding. Lieve Pap en Mam, dat ik zover gekomen ben heeft alles met jullie te maken! 


\section{Curriculum vitae}

De auteur van dit proefschrift werd op 13 september 1961 te Heerlen geboren. Aan de Albert Schweitzer Scholengemeenschap te Geleen werd in 1983 het Atheneum $\beta$ diploma behaald. Eind 1987 werd de studie Gezondheidswetenschappen aan de Rijksuniversiteit Limburg, met als afstudeerrichting Gezondheidsvoorlichting en -opvoeding (GVO), afgesloten. Daama werd zij als wetenschappelijk medewerker bij de vakgroep GVO van de Rijksuniversiteit Limburg aangesteld, waar zij naast onderwijswerkzaamheden met name onderzoek verrichtte. Haar postacademische scholing bestond ondermeer uit deelname aan cursussen op het gebied van de epidemiologie. Zo werden cursussen gevolgd van gerenommeerde epidemiologen zoals Prof. dr. D.G. Kleinbaum, prof. dr. S.J. Pocock en prof. dr. K.J. Rothman. Bovendien werd in de zomer van 1989 aan de universiteit van Medford te Boston, USA, het "New England Epidemiology Summer Program" doorlopen. Daamaast nam zij deel aan postacademisch onderwijs op het gebied van de Gezondheidswoorlichting en -opvoeding, waaronder een cursus 'Relapse prevention' en een cursus 'Voorlichting aan achterstandsgroepen'. 